\title{
What Explains the Proliferation Antidumping Laws?
}

H. Vandenbussche and Maurizio Zanardi

Discussion Paper 2007-27

Département des Sciences Économiques

de l'Université catholique de Louvain 


\title{
What Explains the Proliferation of Antidumping Laws?
}

\author{
Hylke Vandenbussche \\ Université Catholique de Louvain, \\ CORE, KULeuven and CEPR
}

\author{
Maurizio Zanardi \\ Tilburg University and CentER
}

March 15, 2007

\begin{abstract}
A recent phenomenon is the rapid spread of Antidumping (AD) laws mainly amongst developing countries (i.e. China, India, Mexico). Between 1980 and 2003 the number of countries in the world with an $\mathrm{AD}$ law more than doubled going from 36 to 97 countries. This proliferation of trade protection laws amongst developing countries is likely to have substantial implications for trade as recently shown by Vandenbussche and Zanardi (2007). The purpose of this paper is to use a duration analysis to investigate the determinants leading a country to adopt an $\mathrm{AD}$ law. We also analyze the related question of what explains the heterogeneity between countries that can be observed in terms of the time between adoption and their first use of the AD law. We find strong evidence that retaliatory motives are at the heart of the proliferation decision as countries that were targeted by $\mathrm{AD}$ actions of traditional users in the past (i.e., US, EU) are much more likely to adopt an AD law. Also, our evidence suggests that past trade liberalization substantially increases the probability of a country to adopt an AD law. In addition, we find that the size of the chemicals sector and the extent of steel imports are positively correlated with the probability to adopt. The amount of inward FDI on the other hand has a clear negative effect on the probability to adopt. While short term macroeconomic factors like GDP growth and exchange rate volatility seem to matter less for adoption, asymmetric regional shocks and the development level of a country seem to raise the probability of starting to use an AD law. Our results are robust to several specifications of duration models.
\end{abstract}

Keywords: Antidumping, trade liberalization, GATT/WTO

JEL Codes: F13, F14

Paper presented at the $45^{\text {th }}$ Panel Meeting of Economic Policy in Frankfurt (April 2007)

\footnotetext{
Contact addresses: Hylke Vandenbussche, Department of Economics, Université catholique de Louvain, Place Montesquieu 3, 1348 Louvain-la-Neuve, Belgium, T:+32-10-474137, F: +32-16-326732, vandenbussche@core.ucl.ac.be; Maurizio Zanardi, Department of Economics, Tilburg University, P.O. Box 90153, 5000 LE Tilburg, Netherlands, T:+31-13-4663377, F: +31-13-4663042, m.zanardi @uvt.nl. We thank two referees and the editors for editorial guidance during the revision process. A special thank also goes to Ziga Zarnic for research assistance on the data.
} 


\section{INTRODUCTION ${ }^{1}$}

In the past half a century a lot of progress has been made at the multilateral level in terms of trade liberalization. However, the risk of protection is looming again. While tariffs and quotas have been largely reduced, these traditional trade policy instruments have been replaced by an increasing use of other forms of protection, notably antidumping (AD) measures (Lindsey and Ikenson, 2001). While $\mathrm{AD}$ actions are supposedly intended to combat 'unfair trade', by now most economists agree that $\mathrm{AD}$ is not so much about stopping unfair trade but has predominantly become a tool of industrial policy used by countries to foster the interests of their national industries (see Box 1 for more information about the way AD laws are operationalized). ${ }^{2}$

Before 1980s, there were only 5 major users of AD: Australia, Canada, EU, New Zealand and US. These countries have come to be known as the "traditional users". But in the past two decades many more countries have started to adopt and use AD laws, as illustrated in Figure 1. These countries are referred to as the "new users". Most of the adoptions occurred after 1980. In fact, 61 countries adopted an AD law between 1980 and 2003. This proliferation of AD laws predominantly occurred among developing countries (Prusa, 2001). At the same time, some of these countries are taking prominent positions in the global world market. A country like India adopted an AD law in 1985 and had initiated 361 cases by 2003, while China adopted an AD law in 1997 and had started 85 investigations by the end of $2003 .^{3}$

The proliferation of AD laws and their use is likely to have substantial trade effects. A recent paper by Vandenbussche and Zanardi (2007) estimated the trade depressing effects of AD proliferation for some new users to be in the range of $8.9 \%$ of their annual imports. Such estimates seem to refute the notion that AD laws are "a small price to pay" to foster the trade liberalization process. For example, India saw its imports rise by $11.3 \%$ as a result of trade liberalization over the period 1991-2001 but its use of AD reduced imports by 10.2\%, as argued by Vandenbussche and Zanardi (2007). This suggests that adopting and using AD laws can substantially offset gains from trade liberalization, as also suggested by Indian policymakers who in a recent communication to the WTO said that "benefits from trade liberalization have been considerably neutralized by the unfair use of anti-dumping measures" (WTO, 1999).

Today we see that that there has been a shift in the set of countries that rely on AD. While the number of $\mathrm{AD}$ measures by the traditional users has gone down, the highest number of $\mathrm{AD}$ measures per US\$ of imports is now attained by some of the new users, as shown by Finger et al. (2002). Moreover, new users predominantly use AD protection against traditional users, notably the US and

\footnotetext{
${ }^{1}$ The idea for this paper emerged from a conversation with Daron Acemoglu who was visiting the University of Leuven (KUL) for the Gaston Eyskens lectures.

${ }^{2}$ Shin (1998) shows that less than $10 \%$ of US AD cases are about predatory dumping, which is the only instance where $\mathrm{AD}$ measures are economically justified.

${ }^{3}$ As a comparison, the EU and the US initiated on average 31 and 38 cases, respectively, per year during 19952003.
} 
the EU. In the words of Dan Ikenson (2002) from the Cato Institute (a think tank in Washington DC) "the likelihood of continued antidumping proliferation poses a significant threat to US export growth (...) the US has become the third largest target of antidumping actions around the world" and a similar argument applies for the EU as well. Therefore, American and European firms are now themselves under threat of facing $\mathrm{AD}$ actions by developing countries jeopardizing market access to some of the largest growing markets in the world.

From a policy perspective, it is therefore important to investigate the reasons that lead countries to adopt $\mathrm{AD}$ laws. Recent research seems to suggest that in terms of the total use of $\mathrm{AD}$, as measured by the number of initiations and measures, retaliation is at the heart of the problem (Prusa and Skeath, 2002). However, thus far nobody has looked at the underlying motives for countries' adoption of $\mathrm{AD}$ laws in the first place. This brings us to the purpose of this paper where we analyze more generally what are the underlying reasons for countries to adopt AD laws. Or put differently, we want to explain the proliferation of $\mathrm{AD}$ laws using formal methods of analysis. In addition to the adoption decision, this proliferation also holds another interesting question namely what explains the time gap between adoption and the first $\mathrm{AD}$ initiation. Our data reveal substantial heterogeneity amongst adopters in this dimension, which is worth exploring. In view of the time dimension in adoption and first use decision, our empirical analysis employs models of duration (survival) analysis. In particular we will use a parametric Weibull model and a semi-parametric Cox model with a set of explanatory variables drawn from the hypotheses put forward in the literature to explain the overall use of $\mathrm{AD} .^{4}$

As for the decision to adopt, our empirical analysis is based on a set of 108 countries that did not have an AD law in 1980, which is the starting point of our sample period. Of those 108 countries, 61 adopted an AD law at some point between 1980 and 2003, which is the final year of our sample. Our findings indicate that the decision to adopt an $\mathrm{AD}$ law is well explained by the regressors that capture institutional, retaliatory, contagion, safety valve and political economy motives.

The decision of first use is more difficult to pin down partly because we have far fewer observations at our disposal since the duration analysis of first use is only relevant for the 61 countries that adopted an AD law. ${ }^{5}$ Still, our findings suggest that short run retaliatory motives and the level of development of a country matter most in explaining the cross-country variation of the first $\mathrm{AD}$ initiation.

The policy implications arising from our results are multiple and will be discussed in detail in a separate section. Predominantly they call out for the urgent need to renegotiate the AD procedure at the multilateral level, not in the least because the main targets of AD measures by the new adopters are

\footnotetext{
${ }^{4}$ One particularly interesting feature of this methodology is that it does not suffer from endogeneity resulting from reverse causality, which often plagues more traditional regression analysis. The reason is that a country is included in the analysis only until it adopts an AD law (or starts using it).

${ }^{5}$ The set of countries that can be used is further reduced because of data availability.
} 
the traditional AD users such as the US and the EU that have thus far blocked any substantial change to the $\mathrm{AD}$ rules in the absence of an incentive to do so. Failure to do so is likely to result in substantial trade losses as recently argued by Vandenbussche and Zanardi (2007).

The structure of the paper is as follows. In the next section we discuss some arguments that may explain the proliferation of AD laws. These channels will provide the guidelines for the variables to be used in the empirical models on the determinants of adoption and first use of AD laws. Section 3 presents a description of the data while section 4 discusses the methodology that we use. The results are presented in section 5 with their economic significance discussed in section 6 . Section 6 concludes by discussing the policy implications of our empirical results.

\section{[INSERT BOX 1 AROUND HERE -- NOW AT THE END OF THE DOCUMENT]}

\section{WHY DO COUNTRIES ADOPT AN ANTIDUMPING LAW?}

Instead of singling out and presenting one particular theory, we discuss a number of different channels that may influence the decision of a country to adopt and first use AD law. We are unaware of any theoretical or empirical literature that has focused on the adoption decision. Previous literature has mainly focused on explaining the use of AD. A priori, such arguments may also explain a country's decision to adopt an $\mathrm{AD}$ law since the overall use of $\mathrm{AD}$ is conditional on adopting and starting using such laws (see Box 2 for a short literature review of some other effects originating from the use of AD laws).

- Institutional reasons: The adoption of an AD law is not compulsory for WTO membership. However, casual observation suggests that many countries adopt an AD law either a few years before becoming a WTO member or a few years after WTO entry. This can be seen from Table 1 where we list both the date of WTO membership and the date of AD adoption of the countries that we study. It is probably not a coincidence that countries adopt AD laws close to the date of their WTO membership. It suggests that countries regard the AD laws as an integral part of the WTO package even although there is no formal requirement to adopt $\mathrm{AD}$ laws (see Box 1 for more details on the relationship between AD laws and the WTO). Hence, variables related to the time of WTO membership (e.g., years from and to joining the WTO) should be able to show if there is a role for institutional factors in explaining a country's decision to set up an $\mathrm{AD}$ regime.

- Retaliation hypothesis (Blonigen and Bown, 2003; Feinberg and Reynolds, 2006; Prusa and Skeath, 2002): Countries may adopt and use AD laws because of a retaliation motive. In particular, some of the new users (e.g., Brazil, China, India, Mexico) of AD today have previously in the 1980s and 1990s been heavily targeted by AD measures imposed by traditional users like 
the EU and the US. Therefore the recent proliferation of AD laws could be part of a "tit-for-tat" strategy where their adoption of AD laws is driven by the fact that they felt "victimized" by the use of $\mathrm{AD}$ by others against their exporters. The new adopters of $\mathrm{AD}$ may have understood the flexibility of AD actions as trade policy instruments and decided to arm themselves with the same "weapons". In order to investigate this hypothesis, the numbers of past AD investigations and/or measures a country has received are natural explanatory variables for our empirical models.

- Contagion effects: As the number of countries with an AD law increases, it may become more attractive for a country without an AD law to implement one. Prusa referred to it as the "club effect" in his 2001 speech at the CATO Policy Forum. Countries observe other countries using $\mathrm{AD}$ and learn by seeing. The more countries that have $\mathrm{AD}$ laws, the more other countries learn about them, which leads them to join the club and use AD to their own advantage. Such a club may have a geographical dimension. The number of countries with an AD law (worldwide or in a particular geographical area) are natural choices as variables to include in the empirical analysis to test this hypothesis.

- Safety valve hypothesis (Mastel, 1999; Moore, 2005; Niels and ten Kate, 2006): Many developing countries have embarked on trade liberalization reforms during the recent decade (also as a result of their membership in the WTO). In many cases, these trade liberalization efforts resulted in many important structural changes in their economies. In order to smooth some of these shocks and to avoid social conflict in certain sectors, the adoption of an AD law may serve as a safety valve. Another way to explain the safety valve hypothesis is to say that when countries agree to permanently reduce tariffs, they may want to keep their options open and replace tariffs with another form of trade protection that they can use when the need arises to do so. In that sense an AD law can be regarded as some kind of "insurance policy". Also in order for the political class of a country to engage in negotiations on trade liberalization they need a mandate from the majority of their constituents. This majority is easier to find when an "outside option" for protection is still available after the reduction of tariffs. The implementation of AD laws offers such an escape. Empirically, this hypothesis can be tested by including measures of past trade liberalization in our empirical analysis to see whether a reduction of tariffs in the past has contributed to the decision to adopt an AD law in the future.

- Political economy hypothesis (Gawande and Krishna, 2003; Grossman and Helpman, 1994; Hillman, 1982; Nelson, 2006): The adoption and use of an AD law could also be the result of the rent-seeking behavior by special interest groups. These interest groups can be the importcompeting sectors that suffer the most from trade liberalization. Sectors like steel and chemicals have traditionally been applying for protection under $\mathrm{AD}$ laws much more frequently than other 
sectors (Bown, 2004; Irwin, 1998; Blonigen and Prusa, 2003). Several reasons may account for that. Either steel and chemicals are better organized than other sectors which adds to their political clout; or they suffer more from over-capacity making so that it is relatively easy for these sectors to make a case for protection under the current AD laws (see Box 1). Still another reason may be that these sectors typically employ a lot of workers that represent a large share of the voting population resulting in an inclination of governments to protect them relatively more. Interestingly, a casual look at the number of $\mathrm{AD}$ cases in the new adopters of $\mathrm{AD}$ that we study confirms that the steel and chemicals sectors also get a large share of the AD protection although less pronounced than for the traditional users. Together, the new adopters initiated about $29 \%$ of all cases in chemicals and about $25 \%$ in steel during the period of our analysis. In comparison, for a traditional user like the US, steel cases over the same period are much more numerous and represent over $45 \%$ of all cases whereas chemicals only represents $13 \%$ of cases. Clearly, an indication of the size of the domestic steel and chemicals sector and of imports into those sectors could capture the strength of the lobbying power and the rent-seeking behavior of these industries in terms of favoring the adoption of an AD law. Therefore we will include these variables in our empirical analysis. Instead, our presumption is that the size of the agricultural sector would matter less for $\mathrm{AD}$ adoption since this sector is already well protected by other agreements within the WTO. Since the AD law only applies to goods, we also expect the size of the service sector to matter less in the decision to adopt an AD law. Given that AD laws are limited to goods, it seems that especially countries with a large or growing manufacturing sector would benefit most from AD law adoption.

Political economy pressure for protection can also stem from the presence of strong unions defending the interest of workers. ${ }^{6}$ Labor power may matter in two ways: 1) Unions dislike competition since it threatens their power and are more likely to support laws allowing trade protection; 2) Unions are a source of cost-push shocks which can undermine domestic firms competitiveness, hence resulting in a call for the protective use of AD laws (Vandenbussche et al., 2001). For these reasons our analysis should include a measure of union power at the country level.

Also related to the labor markets, standard neo-classical trade models predict that protection affects skilled workers differently than unskilled workers. Therefore the proportion of skilled versus unskilled workers at the country level can be a proxy for the number of advocates versus opponents of protection. The winners and losers from protection depend on the development level of a country. For developed countries skilled workers are supposed to loose from protection while unskilled workers would gain. For developing countries the opposite holds. To verify this hypothesis we will test to what extent the ratio of skilled versus unskilled workers affects the

\footnotetext{
${ }^{6}$ We thank both referees for pointing out the potential role of unions in an earlier draft of this paper.
} 
adoption and first use decision of $\mathrm{AD}$.

- Macro-effects (Knetter and Prusa, 2003): The evidence on the macro effects in earlier work shows that a country's GDP growth and real exchange rate fluctuations have a significant effect on its total AD filings. Smaller and more open economies with flexible exchange rates are more subject to volatile business cycles and may want to implement AD laws to smooth out the business cycle effects. Therefore, current and past macroeconomic conditions will be included in the empirical specifications. We may also want to control for the level of development of a country since arguably it is only those with a sufficient level of development that have the capacity to administer the $\mathrm{AD}$ rules once the $\mathrm{AD}$ law is adopted. And arguably we should also verify to what extent regional or worldwide shocks affect the decisions surrounding AD.

Another macro-variable that may affect the decision to adopt an AD law is the amount of inward foreign direct investment (FDI). In addition to trade flows, globalization has also resulted in the increasing mobility of capital. Hence, the amount of inward FDI that a country receives may affect its attitude vis-à-vis $\mathrm{AD}$ protection. A priori, the higher the inflow of FDI, the lower the probability of AD law adoption. The reason is that the types of products that typically face a lot of $\mathrm{AD}$ protection worldwide are intermediate products. Multinationals are usually more reliant on imports of intermediates from abroad than domestic firms therefore AD laws would hurt their interests. In order to verify the relevance of this argument, our empirical specifications will include a measure of FDI flows.

In addition to traditional macro-indicators, more intangible macro-effects may also play a role. Because of a variety of reasons, countries differ in their political ideology concerning the need for government intervention in the market place. For example, a measure that captures the "beliefs" or the "globalization attitudes" may shape people's (and countries') perception of the need to use trade protection. These beliefs are subject to change over time and are likely to be influenced by the values and the beliefs of the intellectual elite in power. Comparable data on such beliefs for the long list of mainly developing countries in our sample are not available. ${ }^{7}$ Still, data on education may be a proxy for these values and beliefs. In view of the fact that the AD adopters are mainly developing countries, the number of citizens that obtained a Ph.D. in the US may affect a country's views on globalization. This could materialize either by those citizens returning to their country of origin and taking up important positions in society or by those that do not return home but may have an influence through contacts and networks with their country of origin (Rauch, 1999). Our prior is that countries with a large intellectual elite holding Ph.D.s from the US are

\footnotetext{
${ }^{7}$ Various surveys of globalization attitudes are available. However, it is impossible to find comparable data across countries and over time.
} 
likely to be more liberal in their policies and therefore will oppose trade protection more. ${ }^{8}$

The heterogeneity across countries in adoption and first use of $\mathrm{AD}$ will allow us to identify which of these channels is better able to explain the time patterns that are observable in the data. We suspect that the decision to adopt is driven by different motives than the decision to start using AD laws. For example, we expect institutional reasons and safety valve motives to play more of a role in the adoption decision, whereas retaliatory motives are more likely to play a role in the first use of AD. However, only the empirical results will provide an answer to these questions.

\section{[INSERT BOX 2 AROUND HERE -- NOW AT THE END OF THE DOCUMENT]}

\section{DESCRIPTION OF THE DATA}

The sample period for the empirical analysis goes from 1980 until 2003. The starting point of our analysis is mainly motivated by Figure 1 showing that it is only in the 1980s that we observe the beginning of the worldwide proliferation of AD. The endpoint is the result of data availability, in particular with respect to information about adoption of $\mathrm{AD}$ laws (especially for countries that are not members of the WTO). Between 1980 and 2003, 61 countries introduced an AD law with most adoptions occurring in the second half of the 1990s, as shown in Figure 2. This is the set of adopters for the empirical analysis. In addition, our sample will also consist of countries that did not have an AD law by 1980, had not adopted one by the end of 2003 and that had sufficient data availability. ${ }^{9}$ In this sense, our sample includes 108 countries in total. Table 1 lists all the countries in the dataset together with the year when the joined the WTO (if they did) and the year when they adopted and first used an AD law (if they did).

The decision to use an $\mathrm{AD}$ law is conceptually distinct from the decision to adopt an AD law. A comparison between the year of adoption and the year of first use of AD laws uncovers substantial heterogeneity. In fact, almost half (i.e., 27 countries) of all the countries that adopted an AD law during our sample did not begin using AD by the end of 2003 and the time profile of the remaining 34 countries present substantial heterogeneity, as shown in Figure $3 .{ }^{10}$ For example, China initiated its first $\mathrm{AD}$ investigation the same year it adopted the law, while India waited for 7 years. On average there is a three and half years lag between countries' adoption and first use of AD laws. While some countries adopt but never use, some others use it right away. This heterogeneity between countries in terms of first use is a different although equally interesting dimension of the worldwide proliferation

\footnotetext{
${ }^{8}$ Although a similar argument obviously applies for students studying in other developed countries, data limitations force us to use only the US.

${ }^{9}$ Our control group consists of all countries in the worldwide that satisfy these two criteria.

${ }^{10} \mathrm{We}$ do not have any information about the use of AD laws in ten countries that adopted after 1980. In Figure 3 , we assume that they have never used AD.
} 
of $\mathrm{AD}$ and one we intend to analyze. Therefore, we will also model a country's first use of AD law as a separate decision.

Data on worldwide adoptions of AD is an updated version of the dataset from Zanardi (2004a) while the sectoral data on AD initiations and measures comes from Moore and Zanardi (2006). The variables that we use to test the various hypotheses will be discussed in more details along with the results while their description and sources are reported in Table A.1 in the appendix.

\section{METHODOLOGY}

The aim of our empirical models is to investigate the determinants of a country's decision to adopt and subsequently first use of $\mathrm{AD}$ laws. Therefore, we intend to address two separate, though obviously related, issues: the likelihood that a country adopts an $\mathrm{AD}$ law at time $t$, given that it did not have one in 1980; and the time it takes for a country to use such law for the first time after it adopted it. It is important to emphasize that we do not intend to explain the overall use of $\mathrm{AD}$, as there are already several contributions in the literature on this aspect.

These two policy questions can be considered as "events". The time up to an event provides information on what triggered the event (i.e., which explanatory variables are responsible for triggering the event). The appropriate methodology to analyze these decisions is called survival analysis (or event analysis or duration analysis). ${ }^{11}$ Survival analysis techniques have many applications and are especially well known among labor economists that employ them to study issues such as the duration of unemployment.

There are several types of models that can be used in survival analysis. The most important and well-known models are the proportional hazard models. In these versions, the variable that needs to be explained is the "hazard rate" $h_{i}(t)$, which is the probability of an event occurring at a particular moment in time for a particular country $i$. The variables that can potentially explain the occurrence of an event are represented by a set of (time varying) regressors $x_{i t}$ that correspond to the variables that we indicated in order to capture the channels discussed in the section 2. Formally, a hazard model can be presented as follows

$$
h_{i}(t)=h_{0}(t) \exp \left(x_{i t} \beta\right)
$$

where $i$ stands for the country, $t$ for the year, $x_{i t}$ is the matrix of regressors and $\beta$ is the vector of coefficients to be estimated. $h_{0}(t)$ in (1) is called the "baseline hazard rate". The formulation in (1) clarifies why these models are "proportional": any change in the explanatory variables results in a new hazard rate $h_{i}(t)$ that is proportional to the baseline hazard rate independently of the time variable.

Hazard models differ from each other in terms of the assumptions made about the way the

\footnotetext{
${ }^{11}$ Survival analysis deals with the possibility of right censoring (i.e., a subject under investigation does not experience the even by the end of the sample) and the non-normality in the distribution of errors.
} 
baseline hazard rate is specified. ${ }^{12}$ In the case of semi-parametric models (i.e., the Cox model), the baseline hazard rate is left unestimated so that no assumption for the functional form of $h_{0}(t)$ is required. This flexibility comes at the cost of a loss of efficiency with respect to the case where a baseline hazard rate is appropriately modeled. Parametric models do impose a functional form on the baseline hazard rate. Among the many options, the Weibull model is often used because of its generality since it allows the baseline either to be constant, increasing or decreasing over time. In this sense, it nests three alternatives by assuming the following specification:

$$
h_{0}(t)=p t^{p-1} \exp \left(\beta_{0}\right)
$$

where $p>0$ is an ancillary parameter, $t$ is time and $\beta_{0}$ is the constant. The baseline hazard rate is constant if $p$ is equal to 1 while it is increasing (decreasing) for $p$ above (below) 1 .

Arguably, we should not settle for a model where the mere passage of calendar time has some explanatory power. Our aim is to include a sufficient number of plausible regressors such that the regressors explain adoption and first use. In other words, we are going to use a Weibull specification and we will work toward a model where the baseline hazard is not significantly different from 1 , which implies that the baseline hazard rate is constant. ${ }^{13}$ Or put differently, we will add regressors to the model such that there is no "residual" role left for time. As a sensitivity check we will also present the results for the Cox model, which should not systematically differ if the final parameterization of the baseline hazard rate is correct.

The estimates for the coefficients $\beta$ in (1) can be interpreted as the contribution of each regressor to the likelihood of the occurrence of adoption and first use. To facilitate the interpretation of the estimates, we will report our results as hazard ratios (i.e., the exponential of individual coefficients $\beta$ ) since they represent the effect of a one-unit change in the independent variable on the likelihood of adopting or first using AD laws. ${ }^{14}$ What has to be kept in mind, however, is that in this case what matters is whether the hazard ratios are statistically different from one. A hazard ratio that is statistically higher (lower) than one implies a positive (negative) and significant effect on the likelihood of AD law adoption or first use. For example, a hazard ratio of 1.20 for a dummy variable means that the probability of $\mathrm{AD}$ law adoption is $20 \%$ higher when the dummy is equal to one while a hazard ratio of 0.80 would imply a $20 \%$ lower probability. To further simplify comparisons we will also present a table with the effects of a one-standard deviation change in each regressor.

It is important to point out that in a survival analysis framework each country is part of the

\footnotetext{
12 The formulation in (1) clarifies that we intend to estimate a parametric (or possibly semi-parametric) hazard model. Nonparametric models do not impose any structure on the phenomenon under investigation; consequently, they are silent on the effects of potential regressors as determinants of the decision to adopt or first use AD.

${ }^{13}$ Statistical packages usually estimate $\ln (p)$ to guarantee a positive estimate for $\mathrm{p}$. In the tables we will report the estimate of $\ln (p)$ and the implied value of $p$.

${ }^{14}$ Therefore, the scale used in the measurement of each regressor is important. When discussing the economic impact of the variables, we will report the effect of a one standard deviation change on the likelihood to adopt and start using AD laws.
} 
sample up to the year when the decision (to adopt or first use AD) is taken and it disappears afterwards. When analyzing the decision to adopt, all countries start in $1980^{15}$ and they are included until the year when they adopt, or until 2003 if they have not adopted by the end of the sample (i.e., these countries are censored since we do not observe the event $\left.{ }^{16}\right) .{ }^{17}$ Obviously, the decision to use an $\mathrm{AD}$ law is conditional on having first adopted such a law. Therefore, for the second question of interest countries that adopted at some point during our sample period are included from the year of adoption until the year they initiated an AD petition, or until the end of the sample if they have not made use of their AD law by the end of $2003{ }^{18}$

The fact that countries disappear from the data as soon as the event occurs is a particularly interesting feature of survival analysis. In fact, a constant concern when conducting empirical work is the possibility of endogeneity problems if the dependent variable has an effect on the independent variables (i.e., inverse causation). In our opinion, our econometric framework does not suffer from this endogeneity problem since a country disappears from the dataset once adoption/first use occurs. This property of duration models should be stressed. For example, since a country is not included in the duration analysis after the adoption of an $\mathrm{AD}$ law, there cannot be reverse causality running from the adoption of the $\mathrm{AD}$ law to, for example, trade liberalization effects.

However, on top of the regressors that we include in the analysis, there may still be unobserved country level heterogeneity. Suppose there are some unobserved factors that are not included in our analysis but that influence the decision to adopt/use AD law, this will bias the estimates of the coefficients. Duration models allow to control for this possibility by including country specific random effects. In this case, the estimated specification becomes

$$
h_{i}(t)=\alpha_{i} h_{0}(t) \exp \left(x_{i t} \beta\right)
$$

where the effects $\alpha_{i}$ are drawn from a distribution with positive support. These kind of models are called "frailty models" and they will allow us to verify that our results are robust to all country level heterogeneity not explicitly captured by the regressors.

\footnotetext{
${ }^{15}$ Our data are left-censored. This is not too much of a problem if we are willing to assume that, conditional on the covariates, countries faced the same risk of adopting/using an AD law in 1980. In the robustness check, we will also show that the results are unchanged if 1990 is used as the beginning of the analysis.

${ }^{16}$ Our data suffers from right-censoring for those countries that have not adopted/used AD law by 2003. This is not a problem since this censoring is uncorrelated with the covariates.

${ }^{17}$ Countries may enter later if they were born after 1980 (e.g., countries born from the break-up of the Soviet Union).

${ }^{18}$ We have no information about the use or no use of the AD law in ten countries. Therefore, we would be able to use at most 51 countries for a total of 279 observations. As a sensitivity check, we will assume that these ten countries did not use AD.
} 


\section{RESULTS}

In this section, we discuss the results for the two questions that form the objective of the paper. To facilitate the analysis, the results of the empirical models are discussed in two separate sub-sections.

\subsection{Adoption Decision}

We start by analyzing the factors that may influence the adoption of an AD law. For this purpose we have 108 countries in our sample of which 61 adopted an AD law at some point during the period of analysis (1980-2003). This results in 1,843 observations although the exact number of observations included in the various specifications varies depending on data availability.

Our objective is to construct an empirical hazard model that includes all the hypotheses and channels that could have an effect on the adoption decisions. However, for each channel discussed in section 2 we have a set of possible regressors that could be used to test that particular hypothesis. Therefore we start our discussion by an analysis of which variable(s) are best suited to test a particular hypothesis and we report results for two of these alternatives. We then select the variables that perform best and add another channel with the objective of reaching a full model where all the channels are included. We should stress that the sequence in which we test the effect of various hypotheses and consequently build on to a specification entailing all hypotheses is of no particular relevance. However, as we include more variables in the model, observations will be dropped because of missing data. In Table A2 in the appendix we report the results of hazard models containing each channel separately; most of the variables included in the full model are significant.

\section{Institutional effects}

We start in Table 2 by discussing the role of institutional issues in the adoption decision. In column (1) we show a model where we include five different institutional variables: a WTO dummy taking a value of 1 whenever a country is a member of the WTO and zero before, a variable capturing the years before WTO entry and its squared term, and a variable capturing years after WTO entry and its squared term. The WTO dummy controls for the direct effect of membership in the WTO. The second set of variables (i.e., years before WTO entry and it square) checks whether a country adopts an AD law in anticipation of future WTO membership. If at all significant, we would expect a negative effect of this variable since the probability of adoption should be higher the closer a country gets to WTO membership with a possible nonlinear effect since many countries in the sample adopted long before joining the WTO. Instead, we would expect adoption to be more likely in the early years after adopting implying a negative sign for years after WTO entry (although this effect may fade away over time): the smaller the number of years that pass after WTO entry, the more likely a country will adopt an AD law. The results in column (1) of Table 2 show that the WTO dummy is not significant, which may seem surprising at first. However, it is important to note that many of the countries that never adopted an AD law are member of the WTO (see Table 1) and in this sense a dummy variable is not 
able to discriminate between the different experiences of the countries in the sample. Years before WTO membership and its squared term are both significant but not the years after WTO entry. This suggests that there is an anticipation effect of WTO membership that affects AD adoption but that the further apart a country is from WTO membership, the smaller this effect becomes. As for the overall fit of a model that only entails these institutional variables, we clearly see at the bottom of column (1) that there is a positive and significant trend (indicated by the significance of $p$ ) suggesting that there is a lot of unexplained variation. For the same reason, it is not surprising that the Wald test is insignificant: it rejects this specification in favor of one with only a constant, suggesting that the institutional variables included do not have a lot of explanatory power.

In column (1) the years from WTO membership do not seem to matter. But this may be an artifact due to outliers: for those countries that adopted after joining the WTO, the average number of years between the two events is 13 but the median is only 5 years. Based on this median value, we construct another institutional dummy variable that takes the value of 1 whenever a country became a member of the WTO in the past 5 years and a 0 otherwise. Column (2) shows the results. This dummy is highly significant and positive suggesting that when a country is five years or less after WTO membership it becomes very likely that it adopts an $\mathrm{AD}$ law. ${ }^{19}$ Although the positive trend is still significant, the Wald test becomes marginally significant. Considering that the Wald test suggests that this second specification has more explanatory power than the one in column (1), we will build upon column (2) to add the other channels. In terms of number of observations, this specification allows us to include countries that have not yet joined the WTO while they would be excluded because of missing values for years before WTO entry.

\section{Retaliation hypothesis}

In columns (3) and (4) of Table 2 we investigate the retaliation motive for adopting. For this purpose we construct a number of measures. We experimented with total AD initiations/measures received in the current year as well as with total cumulative AD initiations/measures received in the past (from 1980 onwards). Initiations and measures received (cumulated or not) are highly correlated and they all perform relatively well with better results for cumulated measures. In column (3) we report the results for cumulated measures together with the institutional variable selected before (i.e., WTO entry in the past 5 years). The positive and significant sign suggests that a country is more likely to adopt an AD law the more it has been targeted in the past by $\mathrm{AD}$ measures. The new adopters of AD are often those countries whose exporters previously faced AD actions by the traditional users of AD (i.e., Australia, Canada, EU, and US). With the US mainly imposing AD protection in the steel sector and the EU mainly imposing $\mathrm{AD}$ protection on chemicals, it is worth verifying to what extent past $\mathrm{AD}$ measures in steel and chemicals received by the countries in the sample might have had an effect on the decision to

\footnotetext{
${ }^{19}$ We experimented with analogous dummy variables for 3, 7 or 10 years but they were not significant.
} 
adopt an $\mathrm{AD}$ law. For this purpose, we test for the existence of differential retaliation effects driven by steel and chemical cases by constructing a cumulative number of past steel measures and the cumulative number of past chemical measures. In column (4) of Table 2 we see that both of them are highly significant. However, the magnitude of the past steel measures is much higher and also the significance is much stronger than in the case of past chemical measures.

Both versions of the retaliation hypothesis perform very well since the Wald test now firmly rejects a model with only a constant. Instead, the trend is still significant. To capture the retaliation motive in a parsimonious fuller specification our preference is to continue to build on the total cumulative number of AD measures a country has received. It can be verified from Table A.2 in the appendix that including the retaliation variable by itself also yields a positive and significant result. As a sensitivity check later on we will once more introduce a sectoral breakdown of AD measures received to see how this measure of retaliation holds up in a full model.

\section{Contagion hypothesis}

In columns (5) and (6) of Table 2 we look for possible contagion effects. In other words, it could be that a country adopts an AD law because many other countries have adopted one. In column (5) we include the cumulative number of countries that have an $A D$ law in each year in a model that also includes the WTO dummy and the total cumulative number of AD measures received in the past. The contagion variable is not significant. However, when in column (6) we allow for regional contagion effects by including the cumulative number of countries that have an $A D$ law in the same continent, we find a highly positive and significant effect suggesting that there is some kind of herd behavior but only vis-à-vis other countries in the same region.

The other thing to note is that when we include the institutional variables together with the retaliation variable and the regional contagion effect, the ancillary parameter $p$ of the Weibull model is no longer significant. As we discussed in the section on methodology, we should expect this coefficient not to be significant if the regressors are able to explain the decision to adopt. For this reason, we are going to build upon the specification in column (6). We will see in the next table that $p$ remains insignificant when adding the three remaining channels in our building up to a specification entailing all the hypotheses discussed in section 2.

\section{Safety valve hypothesis}

Having selected the regressors to represent the institutional, retaliation and contagion channels, we start by looking at the safety valve channel. Could it be that a country is more inclined to adopt an $\mathrm{AD}$ law when it has recently liberalized its trade and tariffs have come down? In column (1) we capture trade liberalization by including the percentage change (over two years) of an openness index. For this purpose we use the "Freedom to Trade Internationally" index produced by the Simon Fraser Institute in Canada. This index is a measure of tariffs and non-tariff barriers as well as other regulatory factors 
all capturing the general openness of a country. ${ }^{20}$ Although it does not only capture trade liberalization, it has the advantage of being available for a relatively large set of countries and a long time period. Including past trade liberalization in a specification where we also control for institutional, retaliation and contagion effects, as shown in column (7), yields a highly significant and positive hazard ratio on the trade openness index. This is consistent with the safety valve hypothesis: the more a country has opened up to trade recently and the higher the probability of adoption. We should note that Feinberg and Reynolds (2006) have also provided evidence in favor of the safety valve hypothesis between trade liberalization and $\mathrm{AD}$ use. Our result is different, and complements Feinberg and Reynolds', in the sense that we show for the first time that the safety valve hypothesis applies to explaining the adoption of AD laws.

As a robustness check of this result, in the last column of Table 2 we replace the change of the openness index with the change (over two years) in the average applied tariffs as obtained from the World Bank. The result of column (7) is confirmed in the sense that an increase the tariffs reduces the probability of $\mathrm{AD}$ adoption. It should be noted that in a specification where we include only one channel at a time, the change in the trade openness index is not significant while the change in tariffs is (see Table A.2 in the appendix). However, both measures of trade liberalization work well in multivariate specifications and both confirm the safety valve hypothesis (i.e., past trade liberalization raises the probability of $\mathrm{AD}$ adoption). In subsequent specifications of the Weibull model we prefer to keep the trade openness index mainly because its broader time availability results in a much higher number of observations that can be included in the regression with respect to applied tariffs (i.e., 1,201 versus 887 observations). It gives an overall appreciation of the trade openness of a country whereas the tariffs are narrower in coverage.

\section{$\underline{\text { Political economy motives }}$}

In the first five columns of Table 3 we discuss political economy motives. In column (1) we add the value added of industry and the value added of services (as a percentage of GDP) with agriculture as the benchmark. It seems that the bigger the industry and the services vis-à-vis the agricultural sector the more likely a country is to adopt AD law. In column (2) we look at sectoral effects within industry by including the value added of the chemical sector and the value added of the textiles and clothing sector. The reason for including these two sectors is that they have been very active in traditional countries in demanding protection. Ideally we would also like to include the steel industry but unfortunately data limitation thus far has not permitted us to do so. ${ }^{21}$ From column (2) we see that a

\footnotetext{
${ }^{20}$ The index ranges from zero (closed economy) to ten (open economy).

${ }^{21}$ The WDI dataset does not include an indicator of the size of the steel sector. Another database from the World Bank (i.e., the Trade and Production database) does include some sectoral measures but the coverage is really poor resulting in too few observations left for the estimation.
} 
large chemical sector significantly explains the adoption of AD laws, which is not surprising since the chemical sector is among the top users of AD. Instead, the textiles and clothing sector is not significant in explaining the adoption of AD laws, possibly because these sectors were covered by the Multi-Fiber Agreement for the years covered by our sample.

In column (3) of Table 3 we add some variables capturing the import structure of a country. While not shown, we experimented with total imports of goods and services, total exports of goods and services as well as the sum of total imports and exports (all as a percentage of GDP). Neither of these overall trade variables turned out to be significant. As for a sectoral breakdown, the World Development Indicator data that we use covers only a very limited set of sectors: food imports, fuel imports, and ores and metals (as a percentage of total imports). While food and fuel imports (not shown) are not significant, ores and metal imports are always significant implying that a larger import share of ores and metals seems to increase a country's likelihood of adopting and AD law. This comes as no surprise since a large part of these imports are steel products. Indirectly, this variable also measures how important the domestic import competing steel industry is. If the size of imports in steel is an important determinant for adopting an $\mathrm{AD}$ law this may suggest that the import-competing domestic steel industry would like to have an instrument to protect itself against future steel imports and to retaliate against $\mathrm{AD}$ measures imposed by other on its own steel exports.

In column (4) of Table 3 we include a measure of union density measured as the percentage of the working population that is unionized. It is inherently difficult to find good and comparable timevarying measures of union density for developing countries. Not less problematic is the fact that trade unions play very different roles and have very different bargaining powers in different countries. In view of these shortcomings, we could only define time invariant union density dummies. Various cutoff points can be chosen but the results are not sensitive to the choice. Column (4) of table 3 reports the results of a specification with three union dummies: one for density up to $20 \%$ (i.e., the excluded category), one for union density between 21 and 40\%, and one above 40\%. In the estimates reported as well as in other unreported specifications, we fail to find a significant effect of cross-country differences in union density on the decision to adopt an AD law. Including these dummies results in a substantial drop of observations (from 1,113 to 808) while leaving all previously obtained results intact.

As a last variable within the political economy channel we include the country level ratio of skilled over unskilled workers. Such a variable should control for winners and losers from trade protection as predicted by the neo-classical trade theories. The data used comes from the Barro-Lee data set where skilled people are defined as the number of people above 15 years with a secondary school education and above. As shown in column (5), while the coefficient is not significant the ratio of skilled over unskilled people has an hazard rate lower than 1 suggesting that it lowers the probability of $\mathrm{AD}$ law adoption. Including skilled/unskilled leaves all the earlier results intact. Although the coefficient is insignificant, it is in line with the prediction that in sufficiently developed 
countries skilled workers have more to gain from liberalization and therefore are likely to oppose trade protection.

In view of the large number of observations that are lost when including either union density or skilled/unskilled workers and in view of their insignificance, in what follows we prefer to include the industry and services value added as a percentage of GDP as our main political economy variables.

\section{Macro effects}

The last channel we consider in our model aiming to explain the proliferation of AD laws relates to macro effects. We control for macro effects in various ways. In column (6) of Table 3 we include dummy variables for the development level of a country: medium income level countries, high income non-OECD, and high income OECD countries (as defined by the World Bank) with low income countries as the excluded dummy. The definition of these dummies does not change very much over time. Hence, they can be regarded as capturing the level of development of a country and in this way they pick up the cross-sectional differences across countries. Although including these income dummies as macro controls does not change the qualitative results (although some estimates have a lower level of significance), the dummies themselves are not significant. In column (7) we turn to more short run macro controls that substantially vary over time such as GDP growth and the change in the real exchange rate vis-à-vis the US\$ (both over a two year period). Again all the variables in the model remain unchanged but the macro controls do not appear relevant in explaining adoption. Also a measure of GDP variability as a control for the chances that a recession emerges does not seem to be relevant for the adoption decision. Replacing the change in the real exchange rate by a similar measure of variability which may capture a country's change in competitiveness does not seem to have a significant effect on the adoption decision. ${ }^{22}$ It is important to try to understand why macro variables do not seem to explain adoption while in previous studies they have been shown to be important in explaining the use of $\mathrm{AD}$ measures (Knetter and Prusa, 2003). One reason is that here we are explaining the adoption of an $\mathrm{AD}$ law which is a long run decision that is likely to be driven by long run factors rather than short run macro economic evolutions. It will be interesting to see whether short run macro performance indicators are significant determinants in explaining when a country starts using its AD law.

In addition to traditional macro variables it seems also interesting to include an aggregate measure that captures beliefs and attitudes towards trade policy. For this purpose we collected information on the number of citizens with a Ph.D. obtained in the US. While by no means a perfect measure of how beliefs come about or are generated, it does suggest how much the intellectual elite of a country has been exposed to the values and beliefs of a country different from their country of

\footnotetext{
${ }^{22}$ For this purpose we calculated the ratio of standard deviation of GDP (or real exchange rate) to its mean value over the past five years. Results not reported to save on space but available upon request.
} 
citizenship and generally felt to be "liberal". ${ }^{23}$ For this purpose we use data from the US National Science Foundation that are available from 1960 to 1999. The first thing to note is that for most countries in our analysis the number of Ph.D.s obtained in the US has increased substantially. When we include this beliefs measure into our duration model as an extra control variable the previously obtained results remain intact. However, the beliefs variable itself is not significant. This can be seen in column (8) of Table 3. In view of its insignificance we will not take it on board in the full model.

We take column (6) of Table 3 to be our preferred specification of the full model since it is the one with the largest number of observations once we control for all the hypotheses we discussed earlier. Although many observations have been dropped with respect to Table 2, it is important to note that the qualitative results of the first three channels (i.e., institutional, retaliation, contagion) do not change in Table 3. Moreover, we can conclude that the baseline hazard is constant so that the Weibull model that we have been using is equivalent to an exponential model. In other words, the probability of adopting is not affected by the simple passing of time.

\subsubsection{Robustness}

In Table 4 we perform a number of robustness checks of our preferred specification from Table 3. In the first column we alter the institutional variable. Instead of WTO entry in the last 5 years we include the years to the WTO and it square. We see from column (1) that all our results go through and that the years to the WTO are also significant suggesting that for those countries that adopt before WTO entry they do so in anticipation of WTO entry. The next test we carry out in column (2) is to verify our results if we spit up the retaliation variable into the cumulative measures received in steel and the cumulative measures received in chemicals. The results show that the earlier conclusions go through and only the value added of services is not significant anymore. In column (3) of Table 4 we include regional controls in the form of dummies for continents. ${ }^{24}$ None of the continental dummies (not shown) are significant and, importantly, none of our results change.

As an additional measure of globalization, in column (4) the average over the last two years of net inflows of FDI as a percentage of GDP is introduced. The results show that higher inflows of FDI reduce the probability to adopt an $\mathrm{AD}$ law. This is in line with out priors. As argued before, foreign firms are more likely to import intermediates from abroad which can explain their aversion for trade protection involving intermediates such as AD laws.

A close look at the adoption dates shows that most of the countries in our sample adopted an AD law in the course of the nineties. Arguably it would be interesting to split our sample in two periods, one period in the eighties and one in the nineties (see Figure 2). In column (5) of Table 4 we

\footnotetext{
${ }^{23}$ The correlation between this measure and the level of the openness index is 0.36 .

${ }^{24}$ For this specification we do not include the income dummies since they will be highly collinear with some continents.
} 
show the results when we run the full model of $\mathrm{AD}$ adoption on the nineties only. Since in this experiment we limit the time span to ten years, we include shorter macro controls in the form of GDP growth and change in real exchange rate that substantially vary over time. We see that all our selected variables remain significant. ${ }^{25}$ We do not show the results separately for the eighties but we note that the significance on some variables is lost. The only ones continuing to be significant for the eighties are the retaliation measures and the contagion variable.

Another robustness check consists in dropping the low income countries from our sample of countries. It could be argued that low income countries have different (political and economic) priorities which are not captured by our list of regressors and may bias the results. Even if this is the case, the results shown in column (6) illustrate that the low income countries do not bias or drive our results since all the results go through.

Thus far the robustness checks and alternative specifications in Table 4 referred to adding or dropping economic variables, splitting the sample or controlling for unobserved heterogeneity. Instead, in the last two columns we use alternative methodologies. In column (7) we estimate a Weibull model with a frailty which controls for unobserved heterogeneity through random effects. A frailty model is comparable to an analysis with random effects in a panel data setting. ${ }^{26}$ Table 4 shows that our conclusions are unchanged by the inclusion of random effects.

As a final robustness check, we use a Cox semi-parametric model instead of the Weibull parametric model. The Cox model is also a parametric model because it allows the inclusion of regressors, but it is semi-parametric in the sense that it does not assume a hazard rate and hence no value for the ancillary parameter $p$ is shown at the bottom of column (8). ${ }^{27}$ Using the same regressors as in our preferred specification in column (6) of Table 4, we obtain exactly the same qualitative results. This reassures us that the variables we included do a good job in explaining the adoption decision independent of the type of hazard model we use.

In conclusion, the results we reached in Table 4 seem to be robust: institutional factors, retaliation motives, contagion effects, safety valve and political economy motives significantly affect the probability of $\mathrm{AD}$ adoption.

\footnotetext{
${ }^{25}$ The results would be equally unchanged if we were to include the income dummies.

${ }^{26}$ The frailty can be modelled differently depending on the distribution from which the $\alpha_{i}$ in (3) are drawn. The specification in column (7) was estimated assuming an inverse Gaussian distribution. The gamma distribution is another popular choice. Although there is no clear rule to choose among distributions, we note that the effects of covariates differences completely vanishes in gamma frailty models as time goes by while they do not when using an inverse Gaussian distribution (Cleves et al., 2004). Independently of the chosen distribution, frailty models assume that the unobserved heterogeneity is uncorrelated with the other explanatory variables.

${ }^{27}$ The exponential model imposes $p=1$.
} 


\subsection{First Use Decision}

There is substantial heterogeneity across countries as for the time gap between adoption and first use of $\mathrm{AD}$ laws. This observation seems worth exploring since it is a research question that can also be addressed with the same type of methodology we have been using to explain AD adoption.

While other papers have already tried to explain the overall AD use of new users of AD (i.e. Prusa and Skeath, 2002; Bown, 2006), we use a hazard model to explain the time of the first AD initiation given that a country has adopted an AD law during our sample period (1980-2003). Among the 61 countries that adopted an AD law during our sample, we have information on the year of first use for 51 of them (see last column of Table 1). For most of the remainder of our analysis we will not include the remaining 10 countries, although in a sensitivity check we will verify whether including them as if they have never used their AD law makes any difference. We should point out that the number of observations at our disposal to explain the time from adoption to first use is substantially lower than in the adoption case since we now only include countries that adopted an AD law whereas previously we had adopters and non-adopters in the sample. Partly due to this low number of observation (i.e., between 240 and 280) the results are less robust than in the analysis of the adoption decision and conclusions are more fragile.

As argued above, the same reasons that explain the decision to adopt could affect a country's first use of AD. Various specifications of the full model are shown in Table (4).

In Table 4 we do not include WTO related variables since they never turned out to be significant in explaining a country's first use of AD. In the adoption decision we found evidence of an anticipation effect where the probability of a country adopting an AD law increased in view of future WTO membership and right after membership. But it seems that the time lag between adoption and first use does not depend on WTO membership. A quick look at Table 1 offers a likely explanation: most countries adopted an AD law after WTO membership (68\% of those that adopted) which may explain why WTO entry does not affect the time between adoption and first use of the AD law since most countries are already member of the WTO at the time of adoption.

We did experiment with a variable capturing the age of the $A D$ law which resulted in a negative and significant coefficient suggesting that the older the AD law the less likely a country will start using it for the first time. In fact from Figure 3 it already became clear that most countries start using AD laws in the first 3 years after adoption. However, the use of an age variable is problematic in a Weibull model since it conflicts with the ancillary parameter $p$. Moreover, although Figure 3 points out the relevance of age, such a regressor does not have an economic interpretation. If anything, economic regressors should be able to explain the heterogeneity in the time lag between adoption and first use.

What does seem to be very important to explain the time between adoption and first use in all the specifications that we ran is short run retaliation. When we include the lagged value of $A D$ measures received by all trade partners, as in column (1) of Table 5, they affect the first use decision 
in a positive and highly significant way. While cumulative measures in some specifications also holds up, last year's $A D$ measures received always performed stronger independently of the specification. Note that in the adoption model, it became clear that cumulated $A D$ measures were more important than last year's AD measures received. This makes sense since the adoption of an AD law is more of a long run decision which may depend less on short run fluctuations in terms of measures received, whereas the first use of $\mathrm{AD}$ is likely to be triggered by more recent events like the $\mathrm{AD}$ measures domestic exporting firms faced abroad in the past year.

In column (2) we break down the number of $\mathrm{AD}$ measures into those received in chemicals and those received in steel in the previous year. Both of these variables are positive and significant suggesting that short run retaliation is triggered by $\mathrm{AD}$ measures that other countries have imposed against this country's steel and, especially, chemicals' exports. This is indirect evidence that the first users of $\mathrm{AD}$ in our sample have relatively large steel and chemicals industry whose exports are targeted by other countries' measures. We fail to find evidence of a contagion effect, which we measures as the number of active users in each continent. In contrast, in the decision to adopt an $\mathrm{AD}$ law, we found clear evidence of some herd behavior such that adoption was influenced by the adoption behavior of neighboring countries. The first use of AD laws does not seem subject to this same effect. This could also reflect the fact that countries on the same continent do not use AD against each other but rather against countries in different continents.

In all the specifications we see that trade liberalization, as captured by the change in applied tariffs, has the expected sign (i.e., first use of the $\mathrm{AD}$ law is more likely when protection decreases) but is less significant in explaining first use than in the adoption decision. Hence, while the safety valve hypothesis seems to matter, its effect on the decision to first start using $\mathrm{AD}$ is far less present than in the case of adoption. This result could be explained as follows. The safety valve hypothesis was clearly confirmed for the decision to adopt in the sense that past trade liberalization efforts increase the likelihood of AD adoption. Since first use can only occur after AD adoption, it could be that the big push in trade liberalization had already occurred before adoption and thus it is less significant in explaining the time between adoption and first use. Interestingly, the change in the openness index, although not shown, is never significant, possibly because it is too broad a measure of trade liberalization when it comes to explain a specific industry's decision to use the AD law.

In terms of political economy factors, neither the size of the industrial sector nor the size of the service sector in relation to the agricultural sector seems to matter in explaining first use (i.e., first column of Table 5). In column (3) we use the percentage of food imports and ores and metals imports. Imports of food are never significant, most likely because they are covered by separate agricultural agreements in the WTO. As for the imports of ores and metals we find mixed results. While in some specifications (i.e., columns (2) and (3)) they are marginally significant and positive suggesting that imports in ores and basic metals partly explain the first use of $\mathrm{AD}$, they lose their significance when we use different macroeconomic controls such as GDP per capita in column (4). Unfortunately, it is 
not possible to include the size of the chemical and the textiles and clothing sectors along the lines of column (2) of Table 3 because we would be left with less than 160 observations, too few for a meaningful analysis.

While not reported, the inclusion of union density dummies does not affect the results, moreover the dummies are never significant. We also fail to find any correlation between the ratio skilled over unskilled workers and the first use of AD laws. Overall, it seems that political economy factors play less of a role in the decision to start using $\mathrm{AD}$ law than in the adoption decision. But we need to remind ourselves of two important caveats. First, as we already mentioned we have far fewer observations to explain the first use than to explain adoption. Second, due to data limitation our regressors may not be the best suited to capture the political economy channel.

In terms of the macro-economic variables, we find that medium and high income non-OECD countries within the group of adopters have a higher probability of first use than low income countries. ${ }^{28}$ This is consistent with the fact that medium and high income countries have more capacity to manage and implement the AD laws than low income countries that may often lack the expertise to apply all the $\mathrm{AD}$ rules into practice.

A possibility that we have thus far not explored is to what extent regional shocks may affect the demand for protection and increase the probability of a country's first use. Indeed, regional shocks may also drive the significance of the retaliation variable if they simply represent the response of other countries to a common shock. In order to see if regional shocks play a role and if still there is evidence of a retaliation effect, the specification in column (4) of Table 5 includes two additional macrovariables. One is a measure of regional shocks and it is defined as the GDP growth rates of the region a country belongs too. However, as a second variable we also include the growth rate in world GDP to see if regional or global shocks play a role. The results clearly indicate that regional GDP growth significantly affects the decision of first use (i.e., the likelihood of first use increases during a regional expansion) while worldwide shocks do not play any role. This distinction offers an interesting insight. While asymmetric shocks seem to matter for the first use of $\mathrm{AD}$, shocks that hit all countries seem to matter less. Moreover, the retaliation variable remains significant thus confirming its interpretation and not acting as a proxy for regional shocks. A surprising result is that the sign on the regional GDP growth is different from what others have found. Knetter and Prusa (2003) for example find that GDP growth of a country is negatively related to the overall number of AD filings. A possible explanation is that regional growth picks up a more persistent upward trend of development than individual countries' GDP growth rates. In that sense we can understand the positive sign on regional growth rates given that by now it is well known that countries need a certain level of development to build up sufficient capacity to manage AD laws.

\footnotetext{
${ }^{28}$ We had to exclude the dummy variable for high income OECD countries since no country in this group has begun using the AD law during our sample.
} 
Additionally, controlling for the net inflow of FDI does not seem to matter for the first use decision. Similarly, the regressor meant to capture a country's overall beliefs towards globalization is not significant and both specifications will not reported to save on space.

In column (5) we include the 10 countries for which we have no information about their first use. Looking at the list of these countries it seems reasonable to assume that they never used their AD law. The inclusion of these countries does not make any difference on the results.

We note that in all the specifications that we discussed, the ancillary parameter of the Weibull model is never significant so that the baseline hazard rate is constant over time. As final robustness checks related to the methodology, in the last two columns we estimate a Weibull model with frailty and Cox model. The frailty model in column (6) reveals that our result are robust to unobserved heterogeneity modeled as random effects.

As for the Cox model in column (7), the only differences are that past trade liberalization is no longer significant and that the contagion effect is now significant at the $10 \%$ level. The level of development and imports of ores and metals continue to have a positive effect on first use on top of retaliation that is confirmed as the most important determinant of first use.

In sum, our findings suggest that it is much harder to pin down the determinants of the time lag between a country's adoption of an AD law and its first $\mathrm{AD}$ initiation. The only strong conclusion that seems to emerge from Table 5 is that short run retaliatory motives play an important role in triggering the first use. In particular when a country gets hit with outside AD measures on its steel and chemicals' exports, the likelihood of starting to use their own AD law becomes significantly higher. The other relatively robust finding is that only countries with a level of development sufficiently high to develop the capacity to manage AD laws start using them. The importance of all the other variables we included is too specification dependent to draw any clear conclusion from them.

\section{ECONOMIC SIGNIFICANCE}

Ideally we would like to be able to say something on how each channel affects the probability of adoption and first use. Up to this point in the analysis this was not really possible since the hazard ratios reported in the various tables while showing the direction in which an individual regressor affects adoption/first use of $\mathrm{AD}$, can not be easily compared across regressors. The reason is that hazard ratios represent the effect of a one-unit change of the variable of interest and they are sensitive to the measurement unit.

To overcome this problem and to facilitate the comparison of which channel is more economically relevant, in Table 6 we calculate the effects of a one-standard deviation change of each regressor on the probability of adoption and first use of an AD law. Whenever the regressor is a dummy variable, the percentage change reflects the effect of the dummy switching from 0 to 1 . These computations are performed on our preferred specifications (i.e., column (6) of Table 3 for the 
adoption decision and column (2) of Table 5 for the decision of first use). Even this exercise is not completely solving the problem because some variables exhibit much more volatility around their means than others, as seen in Table 6.

For example, the first column of Table 6 shows that having entered the WTO in the last 5 years seems to make a big difference. Recent membership of WTO raises the probability of adopting AD laws by $82.4 \%$. Indeed, this is a large effect but the decision to join the WTO implies a structural change in a country's trade policy and does not come about that easily (on top of not only being a decision that a country can make without the approval of the other members of the WTO).

In terms of retaliation, an increase of about 12 additional $\mathrm{AD}$ measures received in the past (i.e., one standard deviation) raises the probability of adoption in the current year by $14.4 \%$. This seems a more interesting results since it is not rare for some countries to receive that many AD actions in a given year. And a similar comment applies to the effect of past measures on first use. In this case, having received two more $\mathrm{AD}$ measures in the previous year raises the probability of first use in the current year by $22 \%$, which is quite substantial.

The economic impact of the other variables is much more difficult to analyze. For example, trade liberalization matters a lot for both decisions (i.e., about 50\% for adoption and $-35 \%$ for first use) but it is difficult to say how likely such a one-standard deviation change can materialize.

\section{POLICY RELEVANCE}

The fact that many countries have adopted antidumping (AD) laws in recent years provides us with a unique opportunity in time to study the reasons for this $\mathrm{AD}$ proliferation. The new adopters of $\mathrm{AD}$ laws appear to be mainly developing countries. The main purpose of AD laws within the WTO context is supposedly to combat "unfair imports" from abroad. However, economists by now agree that the current WTO AD Agreement is not well equipped to detect true cases of unfair trade (Shin, 1998). This suggests that other considerations may underlie a country's decision to engage in AD policy. These considerations are likely to be more "political" in nature and may have little to do with combating unfair trade.

One of the important conclusions arising from this paper is that retaliation motives underlie both the decision of a country to adopt an $\mathrm{AD}$ law and its decision to start using it. The number of $\mathrm{AD}$ measures a country faced in the recent past seems to be an important trigger for countries to start using $\mathrm{AD}$. This raises serious policy issues since retaliation motives run clearly contrary to the general antidiscriminatory principle that guides the WTO. Interestingly, new adopters direct their AD measures mainly versus the traditional users of $\mathrm{AD}$ that targeted them with $\mathrm{AD}$ measures in the past, notably the US and the EU (Vandenbussche and Zanardi, 2007). With these retaliation motives at work, there is a serious risk of Prisoner's dilemma outcomes where countries engage in too many unwarranted AD cases. On this ground, it seems that there is an urgent need for a substantial tightening of the dumping 
and injury criteria that the $\mathrm{AD}$ authorities are required to use.

Paradoxically, the proliferation of $\mathrm{AD}$ laws and the capacity of developing countries to retaliate may also open up opportunities for change. Until now the political will to change AD laws was largely absent. For many years developing countries have been insisting on a change of the AD rules which they felt were inadequate and were in many cases unjustly hurting the interests of their exporters. However, the traditional users, notably the US and the EU, have always opposed major changes of the AD law. However, the recent proliferation of AD may change the attitude of the US and EU and make them more willing to agree on changes in order to avoid a building up/running up of $\mathrm{AD}$ protection from developing countries which now adversely hurts the traditional exporters. It seems that there are some signs in this direction. The EU Trade Commissioner, Peter Mandelson, has recently released the Green Paper on the EU trade defense instruments where the EU displays its willingness to change. One prominent reason for this has been the recent 2005 "leather shoe" case against China and Vietnam. This case revealed that AD duties were hurting instead of benefiting a large share of the EU producers. ${ }^{29}$ This resulted in large opinion differences between member states in terms of whether or not to impose duties. A compromise was reached by substantially shortening the period for which AD duties apply.

Hopefully, it will become clear that it is in the interest of all AD users to renegotiate the AD rules to make their use less "easy". For a start, AD rules should be guided more by economics principles than purely legal definitions which would tighten its application and reduce the number of type I errors (classify dumping as unfair where it is not). Along this line, changes in the AD law may benefit from the longer experience of competition laws and practices. In fact, economists have long been arguing that $\mathrm{AD}$ laws, if not scraped, should resemble more competition laws (see, among others, Hoekman and Mavroidis, 1996; Messerlin, 1994). In that case we would observe far less AD cases passing the hurdle and resulting in trade protection.

Our analysis also showed that political economy motives underlie AD decisions. We find some evidence that countries with a substantial chemicals and steel sector adopt AD more often and start using it faster than others. This seems to suggest that the chemicals and steel sectors are relatively more successful in rent-seeking and in lobbying to protect their domestic interests. A possible remedy at the level of the WTO would be to tighten the AD rules to make them less subject to rent-seeking from particular sectoral interest groups. One way to accomplish this may be to introduce a Public Interest Clause into the WTO AD Agreement and make it compulsory in any AD law. At present, the WTO AD agreement does not require a public interest test for imposing AD duties. However, an effective public interest clause ensures that $\mathrm{AD}$ protection can only be imposed when it is in the

\footnotetext{
${ }^{29}$ The largest and most efficient EU shoe producers for some time already had been outsourcing the more labour intensive parts of the shoe production process to China and Vietnam. By introducing AD duties on the imports of shoes in the EU, these firms were adversely affected while AD protection mainly benefited the smaller and more inefficient producers.
} 
interest of all domestic parties, including (intermediate and final) consumers. At present only a few countries, including the EU, have such a clause while the large majority of countries do not even pay lip service to consumers' interests. ${ }^{30}$ And even in those countries that officially have a public interest clause (e.g., Argentina, Australia, Canada and EU), its enforcement is, at best, sporadic so that consumers' interests are often equated to domestic producers' interests. A reform at the level of the WTO agreement on AD entailing a clear operational definition of Public Interest would ensure two things. First that all countries include such a test into their national AD law and second that countries clearly have to demonstrate the elements involved in the Public interest test (Sapir, 2006).

The fact that we find that past trade liberalization positively affects a country's adoption of an $\mathrm{AD}$ law suggests that $\mathrm{AD}$ laws are used as a safety valve when an economy becomes more open to trade. This seems to confirm earlier allegations that all that $\mathrm{AD}$ does is to substitute more permanent tariffs with more ad-hoc and selective type of protectionist measures. The danger of this phenomenon is that earlier gains from trade liberalization could be in part offset by welfare losses resulting from the adoption of AD laws. Recently, Vandenbussche and Zanardi (2007) have shown that for the new users of $\mathrm{AD}$, the trade losses resulting from the systematic implementation of an AD policy substantially offset the increase in trade that was obtained under past trade liberalization efforts. However, it is also important to point out that the WTO provides instruments (i.e., safeguards) other than AD to accommodate industries that are substantially and negatively affected by trade liberalization without the need to show unfair imports. The reason why AD actions are more popular measures and far more frequently used than safeguards is that it is more difficult for a country to impose protection under the current safeguards rules due to stricter rules. Already in 1982 Finger et al. (1982) concluded that “Antidumping are functionally the poor (or small) man's escape clause", a conclusion that still holds today. Recognizing the practical (political) unfeasibility of removing AD laws, their legal objective of addressing unfair business practices should be upheld. If safeguards are too difficult to be used, the rules governing their use should be changed instead of using $\mathrm{AD}$ as a second best instrument to wield protection to specific sectors (or firms) in distress.

A closely related argument often offered by $\mathrm{AD}$ supporters is that an $\mathrm{AD}$ law helps trade liberalization since it would provide a way to smooth sudden shifts in import volumes that would cause the displacement of workers and firms. While this is an interesting hypothesis, safeguards or trade-related assistance are a better way to address the problem. Moreover, although the methodology used in this paper did not allow us to investigate to what extent past adoption of AD laws could foster future trade liberalization, empirical evidence from Moore and Zanardi (2006) seems to refute that such channel is at work in developing countries.

Although our results confirm that the level of macro economic development matters for the

\footnotetext{
${ }^{30}$ Interestingly, consumers are mentioned only once in the WTO AD Agreement and only to allow representative consumer organizations to provide relevant information.
} 
first use of $\mathrm{AD}$, we fail to find convincing evidence of the importance of short run macro shocks, possibly due to the lack of sufficient observations. However, in previous studies it has been shown that total use of AD measures is a function of business cycle fluctuations (Knetter and Prusa, 2003). This suggests that $\mathrm{AD}$ is used to shelter domestic firms from negative shocks instead of countering dumping practices. This would imply that the causality investigation in $\mathrm{AD}$ procedures needs to be tightened. The causality clause requires the protecting country to demonstrate a causal link between dumped foreign imports and injury to the domestic industry. This causality is now checked rather loosely. It suffices to show that a downward trend of domestic sales coincides with an increasing trend of imports. Ideally, causality should be established by turning to more sophisticated methodological approaches. A multivariate regression analysis that related injury to dumping and controls for the macroeconomic environment would establish more precisely which elements significantly contributed to the domestic injury and which did not. As an alternative, a simulation approach could be used although this would be more data demanding with regard to the assumptions on various demand and supply elasticity parameters (Sapir and Trachtman, 2007; Grossman and Wauters, 2007). Also in this case, modification could be made to the WTO AD Agreement in order to force AD authorities to conduct more sound economic analyses.

In contrast to short run macro factors we do find that middle and high income countries are more likely to initiate the first AD case than low income countries. This may be related to the capacity to manage the AD laws, which may be simply absent in low income countries despite having adopted the law in the past. If this is the correct interpretation, this result substantiates the claim that the WTO and its trade agreements are not always in the interest of the least developing countries. Our results suggest that only those countries that can afford to build the capacity to administer these AD rules can actually benefit from them while poorer countries are not given a fair chance to use the same instrument.

Adoption and first use are crucial aspects of the proliferation of AD laws. An understanding of countries' decisions on these matters is essential in view of the multilateral trade negotiations taking place at the level of the WTO. Both the EU and the US should welcome the opportunity in the Doha Round, or beyond, to renegotiate the rules of $\mathrm{AD}$ in order to prevent further proliferation and worldwide trade depression of which they seem to become the main target. This is even more relevant since the results presented in this paper show that retaliation motives play a crucial role both in explaining adoption and in triggering the first use of AD. Today it seems that the US is only prepared to discuss the technical aspects of $\mathrm{AD}$ (see Moore, 2005) which is regrettable since adoption and use of $\mathrm{AD}$ laws by new users is resulting in global trade chilling effects as shown recently by Vandenbussche and Zanardi (2007). We should not let AD erode the trade gains that have been achieved through painful trade reforms. Now that we understand better the phenomenon behind the proliferation of $\mathrm{AD}$, efforts can be made to limit it before more welfare gains from past trade liberalization are further eroded. 
Figure 1: Evolution of the number of countries with antidumping laws

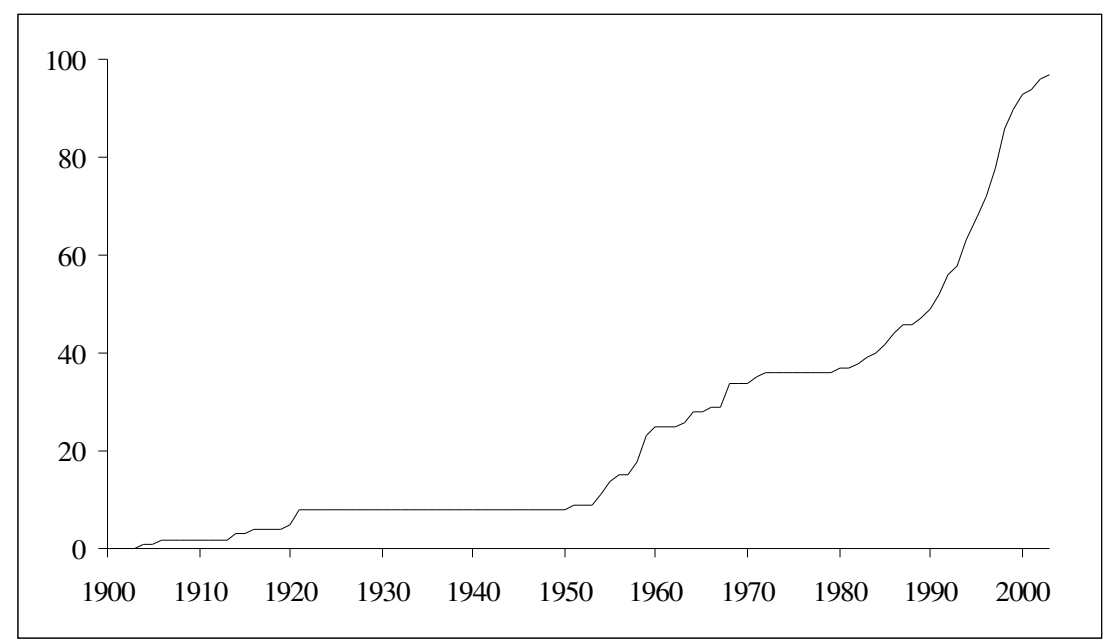

Source: authors' update of Zanardi (2004a).

Figure 2: When did countries adopt antidumping laws?

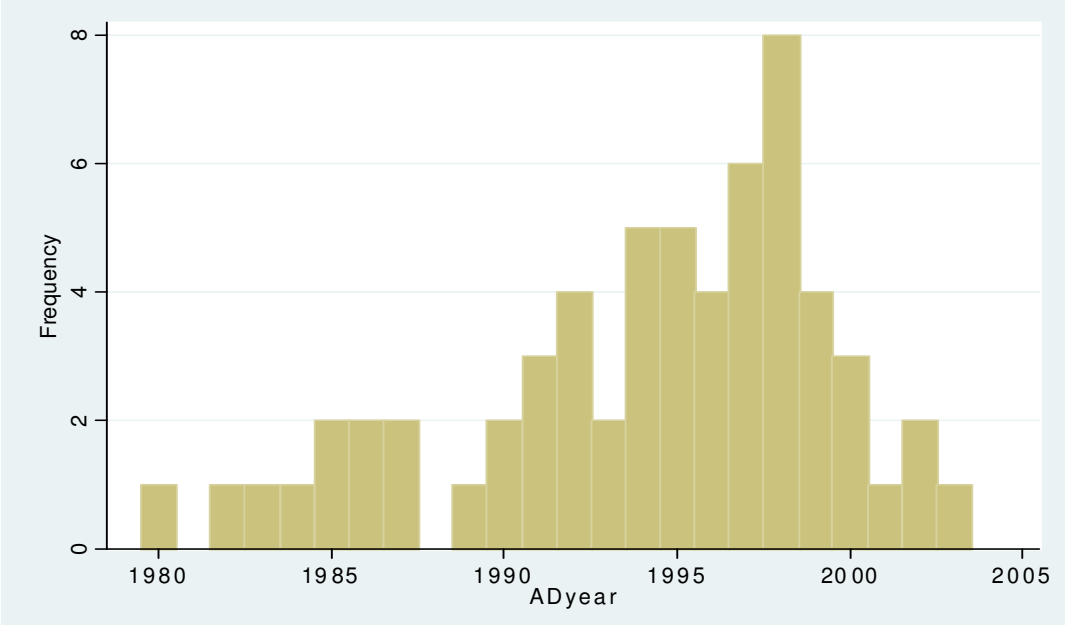

Source: authors' update of Zanardi (2004a).

Figure 3: Time lag between adoption and first use of antidumping laws

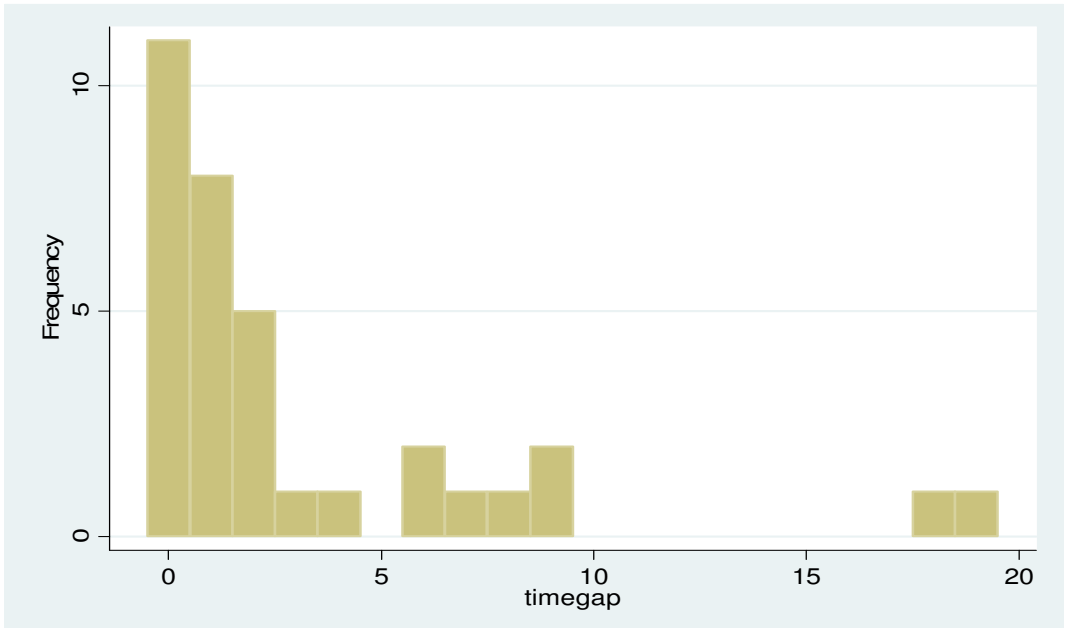

Source: authors' update of Zanardi (2004a). 
Table 1: Countries in the sample (1980-2003)

\begin{tabular}{|c|c|c|c|c|c|}
\hline $\begin{array}{l}\text { Countries that did } \\
\text { not adopt AD law } \\
(1)\end{array}$ & $\begin{array}{c}\text { WTO } \\
\text { membership } \\
(2) \\
\end{array}$ & $\begin{array}{c}\text { Countries that } \\
\text { adopted AD law } \\
(3)\end{array}$ & $\begin{array}{c}\text { WTO } \\
\text { membership } \\
(4) \\
\end{array}$ & $\begin{array}{l}\text { Date of } \\
\text { AD law } \\
(5)\end{array}$ & $\begin{array}{c}\text { Date of first } \\
\text { use of AD law } \\
(6) \\
\end{array}$ \\
\hline Angola & 1994 & Albania & 2000 & 1999 & n.a. \\
\hline Bahrain & 1993 & Armenia & 2003 & 2003 & n.a. \\
\hline Belize & 1983 & Bangladesh & 1972 & 1995 & n.a. \\
\hline Benin & 1963 & Belarus & -- & 1999 & n.a. \\
\hline Botswana & 1987 & Bolivia & 1990 & 1992 & never \\
\hline Brunei Darussalam & 1993 & Brazil & 1948 & 1987 & 1988 \\
\hline Burkina Faso & 1963 & Bulgaria & 1996 & 1993 & 2002 \\
\hline Burundi & 1965 & Cameroon & 1963 & 1998 & n.a. \\
\hline Cambodia & 2004 & Chile & 1949 & 1986 & 1994 \\
\hline Chad & 1963 & China & 2001 & 1997 & 1997 \\
\hline Congo & 1997 & Colombia & 1981 & 1990 & 1991 \\
\hline Côte d'Ivoire & 1963 & Costa Rica & 1990 & 1996 & 1996 \\
\hline Djibouti & 1977 & Croatia & 2000 & 1999 & never \\
\hline Gambia & 1965 & Cuba & 1948 & 1990 & n.a. \\
\hline Georgia & 2000 & Czech Republic & 1993 & 1997 & 1998 \\
\hline Ghana & 1957 & Dominican Rep. & 1950 & 2001 & Never \\
\hline Guinea & 1994 & Ecuador & 1996 & 1991 & 1997 \\
\hline Guinea-Bissau & 1994 & Egypt & 1970 & 1998 & 1998 \\
\hline Guyana & 1966 & El Salvador & 1991 & 1995 & never \\
\hline Haiti & 1950 & Estonia & 1999 & 2002 & n.a. \\
\hline Hong Kong & 1986 & Fiji & 1993 & 1998 & n.a. \\
\hline Macau & 1991 & Guatemala & 1991 & 1996 & 1996 \\
\hline Macedonia, FYR & -- & Honduras & 1994 & 1995 & never \\
\hline Madagascar & 1963 & Hungary & 1973 & 1994 & never \\
\hline Maldives & 1983 & Iceland & 1968 & 1987 & never \\
\hline Mali & 1993 & India & 1948 & 1985 & 1992 \\
\hline Malta & 1964 & Indonesia & 1950 & 1995 & 1996 \\
\hline Mauritius & 1970 & Israel & 1962 & 1991 & 1993 \\
\hline Mongolia & 1997 & Jordan & 2000 & 2003 & never \\
\hline Mozambique & 1992 & Kazakhstan & -- & 1998 & n.a. \\
\hline Myanmar & 1948 & Kyrgyz Republic & 1998 & 1998 & never \\
\hline Namibia & 1992 & Latvia & 1999 & 2000 & 2001 \\
\hline Nepal & 2004 & Lithuania & 2001 & 1998 & 1999 \\
\hline Niger & 1963 & Mexico & 1986 & 1986 & 1987 \\
\hline Oman & 2000 & Moldova & 2001 & 2000 & never \\
\hline Papua New Guinea & 1994 & Morocco & 1987 & 1997 & never \\
\hline Qatar & 1994 & Nicaragua & 1950 & 1995 & 1997 \\
\hline Rwanda & 1966 & Pakistan & 1948 & 1983 & 2002 \\
\hline Sierra Leone & 1964 & Panama & 1997 & 1996 & 1998 \\
\hline Solomon Islands & 1994 & Paraguay & 1994 & 1996 & 1999 \\
\hline Sri Lanka & 1948 & Peru & 1951 & 1991 & 1992 \\
\hline Suriname & 1978 & Philippines & 1979 & 1994 & 1994 \\
\hline Swaziland & 1993 & Poland & 1967 & 1997 & 1997 \\
\hline Switzerland & 1966 & Romania & 1971 & 1992 & never \\
\hline
\end{tabular}


Table 1: Countries in the sample (1980-2003) - continued

\begin{tabular}{|c|c|c|c|c|c|}
\hline $\begin{array}{l}\text { Countries that did } \\
\text { not adopt AD law } \\
\text { (1) }\end{array}$ & $\begin{array}{c}\text { WTO } \\
\text { membership } \\
\text { (2) }\end{array}$ & $\begin{array}{c}\text { Countries that } \\
\text { adopted AD law } \\
\text { (3) }\end{array}$ & $\begin{array}{c}\text { WTO } \\
\text { membership } \\
\text { (4) }\end{array}$ & $\begin{array}{c}\text { Date of } \\
\text { AD law } \\
\text { (5) }\end{array}$ & $\begin{array}{c}\text { Date of first } \\
\text { use of AD law } \\
\text { (6) }\end{array}$ \\
\hline Tanzania & 1961 & Russian Federation & $2007 *$ & 1998 & 2000 \\
\hline Togo & 1964 & Saudi Arabia & 2005 & 2000 & n.a. \\
\hline \multirow[t]{15}{*}{ United Arab Emirates } & 1994 & Senegal & 1963 & 1994 & never \\
\hline & & Singapore & 1973 & 1985 & 1994 \\
\hline & & Slovak Republic & 1993 & 1997 & never \\
\hline & & Slovenia & 1994 & 1993 & 1999 \\
\hline & & Spain & 1963 & 1982 & 1984 \\
\hline & & Taiwan & 2002 & 1984 & 1984 \\
\hline & & Thailand & 1982 & 1994 & 1994 \\
\hline & & Trinidad \& Tobago & 1962 & 1992 & 1996 \\
\hline & & Tunisia & 1990 & 1994 & never \\
\hline & & Turkey & 1951 & 1989 & 1989 \\
\hline & & Ukraine & -- & 1999 & 1999 \\
\hline & & Uruguay & 1953 & 1980 & 1998 \\
\hline & & Uzbekistan & -- & 1997 & never \\
\hline & & Venezuela & 1990 & 1992 & 1992 \\
\hline & & Vietnam & 2006 & 1998 & n.a. \\
\hline
\end{tabular}

Notes: "never" means that the country had not used its AD law by the end of 2003. "n.a." means that no information is known about the usage of AD law for this country. "---" means that the country has not yet joined the WTO. *: we assume that Russia will join the WTO in 2007; this assumption is relevant only for the first column of Tables 2 and 4 where otherwise Russia would be excluded from the regression. 
Table 2: The adoption of antidumping laws

\begin{tabular}{|c|c|c|c|c|c|c|c|c|}
\hline & \multicolumn{2}{|c|}{ Institutional Channel } & \multicolumn{2}{|c|}{ Retaliation } & \multicolumn{2}{|c|}{ Contagion } & \multicolumn{2}{|c|}{ Safety Valve } \\
\hline & (1) & (2) & (3) & (4) & $(5)$ & (6) & (7) & (8) \\
\hline WTO & $\begin{array}{c}0.461 \\
(-1.34)\end{array}$ & $\begin{array}{c}0.933 \\
(-0.23)\end{array}$ & & & & & & \\
\hline Years before WTO entry & $\begin{array}{c}0.662 * * * \\
(-2.54)\end{array}$ & & & & & & & \\
\hline (Years before WTO entry) $^{2}$ & $\begin{array}{l}1.017 * * \\
(2.20)\end{array}$ & & & & & & & \\
\hline Years after WTO entry & $\begin{array}{c}0.961 \\
(-1.15)\end{array}$ & & & & & & & \\
\hline${\text { (Years after WTO entry })^{2}}^{2}$ & $\begin{array}{l}1.001 \\
(0.95)\end{array}$ & & & & & & & \\
\hline WTO entry in past 5 years & & $\begin{array}{l}1.893^{* * *} \\
(2.06)\end{array}$ & $\begin{array}{l}1.743^{*} \\
(1.86)\end{array}$ & $\begin{array}{c}1.830^{* *} \\
(2.03)\end{array}$ & $\begin{array}{l}1.744^{*} \\
(1.86)\end{array}$ & $\begin{array}{c}1.788^{* * *} \\
(1.96)\end{array}$ & $\begin{array}{l}2.618 * * * \\
(2.85)\end{array}$ & $\begin{array}{l}2.078 * * * \\
(2.44)\end{array}$ \\
\hline $\begin{array}{l}\text { Cumulated } \mathrm{AD} \text { measures } \\
\text { received in the past }\end{array}$ & & & $\begin{array}{l}1.015^{* * * *} \\
(4.63)\end{array}$ & & $\begin{array}{l}1.015^{* * * *} \\
(4.63)\end{array}$ & $\begin{array}{l}1.017 * * * \\
(5.61)\end{array}$ & $\begin{array}{l}1.015^{* * *} \\
(5.04)\end{array}$ & $\begin{array}{c}1.014 * * * * \\
(4.70)\end{array}$ \\
\hline $\begin{array}{l}\text { Cumulated } \mathrm{AD} \text { measures in } \\
\text { steel in the past }\end{array}$ & & & & $\begin{array}{c}1.100 * * * \\
(5.35)\end{array}$ & & & & \\
\hline $\begin{array}{l}\text { Cumulative } \mathrm{AD} \text { measures } \\
\text { in chemicals in the past }\end{array}$ & & & & $\begin{array}{c}1.025^{* *} \\
(2.45)\end{array}$ & & & & \\
\hline $\begin{array}{l}\text { Number of AD laws in the } \\
\text { world }\end{array}$ & & & & & $\begin{array}{c}0.999 \\
(-0.06)\end{array}$ & & & \\
\hline $\begin{array}{l}\text { Number of AD laws in the } \\
\text { same continent }\end{array}$ & & & & & & $\begin{array}{l}1.220 * * * \\
(6.47)\end{array}$ & $\begin{array}{l}1.220 * * * \\
(5.76)\end{array}$ & $\begin{array}{c}1.214 * * * \\
(5.31)\end{array}$ \\
\hline$\% \Delta$ Openness Index & & & & & & & $\begin{array}{l}1.034 * * \\
(2.35)\end{array}$ & \\
\hline$\% \Delta$ Applied Tariffs & & & & & & & & $\begin{array}{c}0.990^{* *} \\
(-2.05)\end{array}$ \\
\hline $\operatorname{Ln}(p)$ & $\begin{array}{c}0.559 * * * \\
(3.57)\end{array}$ & $\begin{array}{c}0.686 * * * \\
(4.58)\end{array}$ & $\begin{array}{c}0.710^{* * * *} \\
(4.79)\end{array}$ & $\begin{array}{c}0.692^{* * * *} \\
(4.63)\end{array}$ & $\begin{array}{c}0.724 * * \\
(2.30)\end{array}$ & $\begin{array}{l}0.194 \\
(1.16)\end{array}$ & $\begin{array}{l}0.080 \\
(0.44)\end{array}$ & $\begin{array}{l}-0.310 \\
(-0.70)\end{array}$ \\
\hline $\mathrm{p}$ & 1.749 & 1.986 & 2.034 & 1.998 & 2.064 & 1.215 & 1.083 & 0.733 \\
\hline Observations & 1,797 & 1,843 & 1,795 & 1,795 & 1,795 & 1,795 & 1,201 & 887 \\
\hline Countries included & 103 & 108 & 108 & 108 & 108 & 108 & 81 & 95 \\
\hline Countries adopting $\mathrm{AD}$ law & 57 & 61 & 60 & 60 & 60 & 60 & 50 & 49 \\
\hline Wald $\chi^{2}$ & 8.20 & $4.60^{*}$ & $23.40 * * *$ & $65.44 * * *$ & $23.40 * * *$ & $77.59 * * *$ & $67.65 * * *$ & $86.40^{* * *}$ \\
\hline
\end{tabular}

Notes: The table reports hazard ratios with robust z-statistics of the underling point estimates in brackets. A coefficient above (below) 1 implies that the variable has a positive (negative) effect on the likelihood of adoption. $p$ is the ancillary parameter of the Weibull model. $*$ denotes significance at the $10 \%$ level, $* * 5 \%$ level, and *** $1 \%$ level. 
Table 3: The adoption of antidumping laws - continued

\begin{tabular}{|c|c|c|c|c|c|c|c|c|}
\hline & \multicolumn{5}{|c|}{ Political Economy } & \multicolumn{3}{|c|}{ Macro Effects } \\
\hline & (1) & (2) & (3) & (4) & (5) & (6) & (7) & (8) \\
\hline WTO entry in past 5 years & $\begin{array}{l}2.087 * * \\
(2.01)\end{array}$ & $\begin{array}{l}2.003 * \\
(1.85)\end{array}$ & $\begin{array}{l}2.477 * * * * \\
(2.53)\end{array}$ & $\begin{array}{l}2.384 * * * \\
(2.68)\end{array}$ & $\begin{array}{l}2.630 * * * \\
(2.61)\end{array}$ & $\begin{array}{l}1.824^{*} \\
(1.88)\end{array}$ & $\begin{array}{l}2.211 * * \\
(2.10)\end{array}$ & $\begin{array}{c}2.108^{* *} \\
(2.22)\end{array}$ \\
\hline $\begin{array}{l}\text { Cumulated } \mathrm{AD} \text { measures } \\
\text { received in the past }\end{array}$ & $\begin{array}{c}1.013 * * * \\
(4.29)\end{array}$ & $\begin{array}{c}1.008^{* * * *} \\
(3.68)\end{array}$ & $\begin{array}{c}1.010^{* * * *} \\
(2.60)\end{array}$ & $\begin{array}{c}1.011^{* * * *} \\
(3.24)\end{array}$ & $\begin{array}{c}1.013 * * * \\
(5.28)\end{array}$ & $\begin{array}{c}1.011^{* * * *} \\
(3.92)\end{array}$ & $\begin{array}{c}1.014 * * * * \\
(4.41)\end{array}$ & $\begin{array}{c}1.013^{* * *} \\
(3.94)\end{array}$ \\
\hline $\begin{array}{l}\text { Number of AD laws in the } \\
\text { same continent }\end{array}$ & $\begin{array}{c}1.217 * * * \\
(4.79) \\
\end{array}$ & $\begin{array}{c}1.256^{* * * *} \\
(4.70) \\
\end{array}$ & $\begin{array}{c}1.169 * * * \\
(4.11)\end{array}$ & $\begin{array}{c}1.169 * * * \\
(4.07)\end{array}$ & $\begin{array}{c}1.292 * * * \\
(4.43)\end{array}$ & $\begin{array}{c}1.209 * * * * \\
(4.40) \\
\end{array}$ & $\begin{array}{c}1.220 * * * \\
(4.78) \\
\end{array}$ & $\begin{array}{c}1.204 * * * \\
(4.63)\end{array}$ \\
\hline$\% \Delta$ Openness index & $\begin{array}{l}1.052 * * * \\
(3.21)\end{array}$ & $\begin{array}{l}1.035^{* *} \\
(2.96)\end{array}$ & $\begin{array}{c}1.045^{* *} \\
(2.37)\end{array}$ & $\begin{array}{l}1.037 * * \\
(2.21)\end{array}$ & $\begin{array}{l}1.022 \\
(0.95)\end{array}$ & $\begin{array}{l}1.050 * * * \\
(2.98)\end{array}$ & $\begin{array}{l}1.054 * * * \\
(2.67)\end{array}$ & $\begin{array}{c}1.049^{* * * *} \\
(3.10)\end{array}$ \\
\hline Industry VA (\% GDP) & $\begin{array}{c}1.039 * * * \\
(2.87)\end{array}$ & & & & & $\begin{array}{c}1.036^{* *} \\
(2.39)\end{array}$ & $\begin{array}{c}1.036 * * * \\
(2.67)\end{array}$ & $\begin{array}{c}1.045^{* * *} \\
(3.20)\end{array}$ \\
\hline Services VA (\% GDP) & $\begin{array}{c}1.029^{* *} \\
(1.97)\end{array}$ & & & & & $\begin{array}{l}1.029 * \\
(1.64)\end{array}$ & $\begin{array}{l}1.027 * \\
(1.83)\end{array}$ & $\begin{array}{c}1.035^{* *} \\
(2.15)\end{array}$ \\
\hline $\begin{array}{l}\text { Chemicals (\% VA of } \\
\text { manufacturing) }\end{array}$ & & $\begin{array}{c}1.078^{* * * *} \\
(2.96)\end{array}$ & & & & & & \\
\hline $\begin{array}{l}\text { Textiles \& clothing (\% VA } \\
\text { of manufacturing) }\end{array}$ & & $\begin{array}{c}0.988 \\
(-0.79)\end{array}$ & & & & & & \\
\hline $\begin{array}{l}\text { Food imports (\% of total } \\
\text { imports) }\end{array}$ & & & $\begin{array}{c}0.981 \\
(-0.74)\end{array}$ & & & & & \\
\hline $\begin{array}{l}\text { Ore and metal imports (\% } \\
\text { of total imports) }\end{array}$ & & & $\begin{array}{l}1.224^{*} \\
(1.85)\end{array}$ & & & & & \\
\hline $\begin{array}{l}\text { Union density between } \\
21-40 \%\end{array}$ & & & & $\begin{array}{c}0.801 \\
(-0.66)\end{array}$ & & & & \\
\hline Union density above $40 \%$ & & & & $\begin{array}{l}1.082 \\
(0.18)\end{array}$ & & & & \\
\hline Skill/unskilled population & & & & & $\begin{array}{c}0.851 \\
(-0.40)\end{array}$ & & & \\
\hline Medium income & & & & & & $\begin{array}{l}1.806 \\
(1.12)\end{array}$ & & \\
\hline High income non-OECD & & & & & & $\begin{array}{c}0.791 \\
(-0.22)\end{array}$ & & \\
\hline High income OECD & & & & & & $\begin{array}{c}0.788 \\
(-0.17)\end{array}$ & & \\
\hline GDP growth & & & & & & & $\begin{array}{c}0.989 \\
(-0.71)\end{array}$ & \\
\hline$\% \Delta$ Real exchange rate & & & & & & & $\begin{array}{c}0.999 \\
(-0.62)\end{array}$ & \\
\hline Beliefs & & & & & & & & $\begin{array}{l}0.0002 \\
(-0.72)\end{array}$ \\
\hline $\operatorname{Ln}(p)$ & $\begin{array}{l}0.105 \\
(0.53)\end{array}$ & $\begin{array}{l}0.232 \\
(1.04)\end{array}$ & $\begin{array}{l}0.296 \\
(1.47)\end{array}$ & $\begin{array}{l}0.284 \\
(1.34)\end{array}$ & $\begin{array}{l}0.098 \\
(0.47)\end{array}$ & $\begin{array}{l}0.141 \\
(0.65)\end{array}$ & $\begin{array}{l}0.115 \\
(0.53)\end{array}$ & $\begin{array}{l}0.147 \\
(0.71)\end{array}$ \\
\hline $\mathrm{P}$ & 1.111 & 1.261 & 1.345 & 1.329 & 1.103 & 1.151 & 1.122 & 1.158 \\
\hline Observations & 1,113 & 628 & 840 & 808 & 917 & 1,113 & 1,079 & 1,090 \\
\hline Countries included & 80 & 60 & 80 & 61 & 31 & 80 & 78 & 79 \\
\hline Countries adopting $\mathrm{AD}$ law & 49 & 37 & 47 & 47 & 37 & 49 & 48 & 49 \\
\hline Wald $\chi^{2}$ & $71.09^{* * *}$ & $67.46 * * *$ & $54.78 * * *$ & $40.65^{* * *}$ & $66.14 * * *$ & $66.48 * * *$ & $69.30 * * *$ & $71.99 * * *$ \\
\hline
\end{tabular}

Notes: The table reports hazard ratios with robust z-statistics of the underling point estimates in brackets. A coefficient above (below) 1 implies that the variable has a positive (negative) effect on the likelihood of adoption. $p$ is the ancillary parameter of the Weibull model. * denotes significance at the $10 \%$ level, $* * 5 \%$ level, and $* * * 1 \%$ level. 
Table 4: Robustness checks

\begin{tabular}{|c|c|c|c|c|c|c|c|c|}
\hline & $\begin{array}{c}\text { Institutional } \\
\text { Channel } \\
\text { (1) }\end{array}$ & $\begin{array}{c}\begin{array}{c}\text { Sectoral } \\
\text { Retaliation }\end{array} \\
(2)\end{array}$ & $\begin{array}{c}\text { Regional } \\
\text { Dummies } \\
(3)\end{array}$ & $\begin{array}{l}\text { FDI } \\
(4)\end{array}$ & $\begin{array}{c}\text { Only } \\
1990 s \\
(5)\end{array}$ & $\begin{array}{c}\text { No Low } \\
\text { Income } \\
\text { Countries } \\
(6)\end{array}$ & $\begin{array}{c}\text { Frailty } \\
\text { Model } \\
\text { (7) }\end{array}$ & (8) \\
\hline Years before WTO entry & $\begin{array}{c}0.721 * * * \\
(-2.73)\end{array}$ & & & & & & & \\
\hline (Years before WTO entry $)^{2}$ & $\begin{array}{c}1.018^{* * * *} \\
(3.06)\end{array}$ & & & & & & & \\
\hline WTO entry in past 5 years & & $\begin{array}{l}1.972^{* *} \\
(2.12)\end{array}$ & $\begin{array}{c}2.118^{* * *} \\
(2.24)\end{array}$ & $\begin{array}{c}2.028^{* *} \\
(2.40)\end{array}$ & $\begin{array}{l}2.791 * * * \\
(2.56)\end{array}$ & $\begin{array}{c}2.071^{* *} \\
(2.26)\end{array}$ & $\begin{array}{c}2.387^{* *} \\
(2.30)\end{array}$ & $\begin{array}{c}2.150^{* *} \\
(2.39)\end{array}$ \\
\hline $\begin{array}{l}\text { Cumulated } \mathrm{AD} \text { measures } \\
\text { received in the past }\end{array}$ & $\begin{array}{c}1.015 * * * \\
(5.39)\end{array}$ & & $\begin{array}{c}1.008^{* *} \\
(2.02)\end{array}$ & $\begin{array}{l}1.015^{* * * *} \\
(5.40)\end{array}$ & $\begin{array}{l}1.014 * * * \\
(4.21)\end{array}$ & $\begin{array}{l}1.011^{* * * *} \\
(4.14)\end{array}$ & $\begin{array}{c}1.018^{* *} \\
(2.18)\end{array}$ & $\begin{array}{l}1.012 * * * \\
(3.73)\end{array}$ \\
\hline $\begin{array}{l}\text { Cumulated AD measures in } \\
\text { steel in the past }\end{array}$ & & $\begin{array}{l}1.059 * * * \\
(3.94)\end{array}$ & & & & & & \\
\hline $\begin{array}{l}\text { Cumulative } \mathrm{AD} \text { measures in } \\
\text { chemicals in the past }\end{array}$ & & $\begin{array}{l}1.022^{* * *} \\
(2.36)\end{array}$ & & & & & & \\
\hline $\begin{array}{l}\text { Number of AD laws in the same } \\
\text { continent }\end{array}$ & $\begin{array}{l}1.210 * * * \\
(4.41)\end{array}$ & $\begin{array}{l}1.198 * * * \\
(4.26)\end{array}$ & $\begin{array}{l}1.169 * * * \\
(2.88)\end{array}$ & $\begin{array}{l}1.270 * * * \\
(5.75)\end{array}$ & $\begin{array}{l}1.224 * * * \\
(4.15)\end{array}$ & $\begin{array}{l}1.211^{* * *} \\
(4.14)\end{array}$ & $\begin{array}{l}1.323 * * * \\
(3.79)\end{array}$ & $\begin{array}{l}1.377 * * * \\
(5.24)\end{array}$ \\
\hline$\% \Delta$ Openness index & $\begin{array}{l}1.044 * * * \\
(2.55)\end{array}$ & $\begin{array}{c}1.050 * * * \\
(3.05)\end{array}$ & $\begin{array}{c}1.041^{* * *} \\
(2.25)\end{array}$ & $\begin{array}{c}1.046 * * * \\
(2.53)\end{array}$ & $\begin{array}{c}1.065^{* * * *} \\
(2.85)\end{array}$ & $\begin{array}{c}1.057 * * * \\
(2.58)\end{array}$ & $\begin{array}{l}1.051 * * * \\
(2.69)\end{array}$ & $\begin{array}{c}1.047 * * * \\
(2.62)\end{array}$ \\
\hline Industry VA (\% GDP) & $\begin{array}{c}1.041^{* * *} \\
(2.47)\end{array}$ & $\begin{array}{l}1.030^{* *} \\
(2.03)\end{array}$ & $\begin{array}{l}1.048 * * * \\
(2.86)\end{array}$ & $\begin{array}{l}1.038 * * * \\
(2.56)\end{array}$ & $\begin{array}{l}1.034^{* *} \\
(0.015)\end{array}$ & $\begin{array}{l}1.035^{*} \\
(1.74)\end{array}$ & $\begin{array}{c}1.046^{* *} \\
(2.20)\end{array}$ & $\begin{array}{l}1.048 * * * \\
(3.03)\end{array}$ \\
\hline Services VA (\% GDP) & $\begin{array}{l}1.033^{*} \\
(1.75)\end{array}$ & $\begin{array}{l}1.027 \\
(1.57)\end{array}$ & $\begin{array}{l}1.029 \\
(1.62)\end{array}$ & $\begin{array}{c}1.032 * * \\
(2.02)\end{array}$ & $\begin{array}{l}1.023 \\
(1.54)\end{array}$ & $\begin{array}{l}1.020 \\
(0.91)\end{array}$ & $\begin{array}{c}1.044^{* *} \\
(1.99)\end{array}$ & $\begin{array}{l}1.044 * * * \\
(2.53)\end{array}$ \\
\hline Medium income & $\begin{array}{l}1.971 \\
(1.26)\end{array}$ & $\begin{array}{l}1.827 \\
(1.13)\end{array}$ & & $\begin{array}{l}1.959 \\
(1.23)\end{array}$ & & $\begin{array}{l}2.001 \\
(0.54)\end{array}$ & $\begin{array}{l}1.351 \\
(0.46)\end{array}$ & $\begin{array}{c}0.971 \\
(-0.05)\end{array}$ \\
\hline High income non-OECD & $\begin{array}{c}0.721 \\
(-0.32)\end{array}$ & $\begin{array}{c}0.901 \\
(-0.10)\end{array}$ & & $\begin{array}{c}21.394 * * * \\
(3.30)\end{array}$ & & $\begin{array}{c}0.996 \\
(-0.51)\end{array}$ & $\begin{array}{c}0.530 \\
(-0.51)\end{array}$ & $\begin{array}{c}0.446 \\
(-0.79)\end{array}$ \\
\hline High income OECD & $\begin{array}{c}0.589 \\
(-0.38)\end{array}$ & $\begin{array}{c}0.957 \\
(-0.03)\end{array}$ & & $\begin{array}{c}0.769 \\
(-0.18)\end{array}$ & & & $\begin{array}{c}0.789 \\
(-0.11)\end{array}$ & $\begin{array}{c}0.413 \\
(-0.67)\end{array}$ \\
\hline GDP growth & & & & & $\begin{array}{c}0.984 \\
(-0.96)\end{array}$ & & & \\
\hline$\% \Delta$ Real exchange rate & & & & & $\begin{array}{l}1.000 \\
(0.10)\end{array}$ & & & \\
\hline FDI & & & & $\begin{array}{c}0.806^{* * * *} \\
(-4.65)\end{array}$ & & & & \\
\hline $\operatorname{Ln}(p)$ & $\begin{array}{l}0.122 \\
(0.53)\end{array}$ & $\begin{array}{l}0.149 \\
(0.68)\end{array}$ & $\begin{array}{l}0.387 \\
(1.61)\end{array}$ & $\begin{array}{l}0.290 \\
(1.13)\end{array}$ & $\begin{array}{c}0.187 \\
(-0.20)\end{array}$ & $\begin{array}{l}0.204 \\
(0.79)\end{array}$ & $\begin{array}{l}0.051 \\
(0.22)\end{array}$ & - \\
\hline $\mathrm{p}$ & 1.130 & 1.161 & 1.472 & 1.337 & 0.829 & 1.227 & 1.053 & - \\
\hline Observations & 1,110 & 1,113 & 1,113 & 1,010 & 547 & 670 & 1,113 & 1,113 \\
\hline Countries included & 79 & 80 & 80 & 75 & 68 & 56 & 80 & 80 \\
\hline Countries adopting $\mathrm{AD}$ law & 48 & 49 & 49 & 49 & 38 & 43 & 49 & 49 \\
\hline Wald $\chi^{2}$ & $110.59^{* * *}$ & $110.71^{* * *}$ & $66.96 * * *$ & $139.28 * * *$ & $61.93 * * *$ & $42.93 * * *$ & $103.04 * * *$ & $94.44 * * *$ \\
\hline
\end{tabular}

Notes: The table reports hazard ratios with robust z-statistics of the underling point estimates in brackets. A coefficient above (below) 1 implies that the variable has a positive (negative) effect on the likelihood of adoption. $p$ is the ancillary parameter of the Weibull model. * denotes significance at the $10 \%$ level, ** 5\% level, and *** 1\% level. The regional dummies included in column (3) are Africa, North America, Central America, South America, South-East Asia, Europe, Middle East and Oceania; Asia is the excluded category. The frailty model in column (7) assumes an inverse Gaussian distribution for the random effects. 
Table 5: The first use of antidumping laws

\begin{tabular}{|c|c|c|c|c|c|c|c|}
\hline & (1) & (2) & $\begin{array}{c}\begin{array}{c}\text { Sectoral } \\
\text { Retaliation }\end{array} \\
(3)\end{array}$ & $\begin{array}{c}\text { Regional } \\
\text { shocks } \\
(4)\end{array}$ & $\begin{array}{c}\text { All } \\
\text { countries } \\
(5)\end{array}$ & $\begin{array}{c}\text { Frailty } \\
(6)\end{array}$ & $\begin{array}{c}\text { Cox } \\
\text { Model } \\
(7)\end{array}$ \\
\hline $\begin{array}{l}\text { AD measures received in the } \\
\text { previous year }\end{array}$ & $\begin{array}{c}1.128 * * * \\
(4.09)\end{array}$ & $\begin{array}{l}1.110 * * * \\
(4.26)\end{array}$ & & $\begin{array}{c}1.104 * * * \\
(3.71)\end{array}$ & $\begin{array}{l}1.132 * * * \\
(5.66)\end{array}$ & $\begin{array}{c}1.196 * * * \\
(4.17)\end{array}$ & $\begin{array}{l}1.091 * * * \\
(4.17)\end{array}$ \\
\hline $\begin{array}{l}\text { AD measures received in } \\
\text { chemicals in the previous year }\end{array}$ & & & $\begin{array}{c}1.316^{* * * *} \\
(4.33)\end{array}$ & & & & \\
\hline $\begin{array}{l}\text { AD measures received in steel in } \\
\text { the previous year }\end{array}$ & & & $\begin{array}{c}1.061 * * \\
(1.96)\end{array}$ & & & & \\
\hline $\begin{array}{l}\text { Number of active AD laws in the } \\
\text { same continent }\end{array}$ & $\begin{array}{l}1.039 \\
(0.51)\end{array}$ & $\begin{array}{l}1.034 \\
(0.53)\end{array}$ & $\begin{array}{l}1.043 \\
(0.67)\end{array}$ & $\begin{array}{l}1.033 \\
(0.48)\end{array}$ & $\begin{array}{l}1.003 \\
(0.05)\end{array}$ & $\begin{array}{l}1.082 \\
(0.79)\end{array}$ & $\begin{array}{l}1.092^{*} \\
(1.79)\end{array}$ \\
\hline$\% \Delta$ Applied tariffs & $\begin{array}{l}0.988^{*} \\
(-1.65)\end{array}$ & $\begin{array}{l}0.987 * \\
(-1.67)\end{array}$ & $\begin{array}{l}0.987 * \\
(-1.72)\end{array}$ & $\begin{array}{l}0.988 \\
(-1.43)\end{array}$ & $\begin{array}{l}0.985^{*} \\
(-1.79)\end{array}$ & $\begin{array}{l}0.979^{*} \\
(-1.81)\end{array}$ & $\begin{array}{c}0.991 \\
(-1.28)\end{array}$ \\
\hline Industry VA (\% GDP) & $\begin{array}{c}0.993 \\
(-0.12)\end{array}$ & & & & & & \\
\hline Services VA (\% GDP) & $\begin{array}{c}0.986 \\
(-0.42)\end{array}$ & & & & & & \\
\hline Food imports ( $\%$ of total imports) & & $\begin{array}{l}1.006 \\
(0.17)\end{array}$ & $\begin{array}{l}1.025 \\
(0.62)\end{array}$ & $\begin{array}{l}1.019 \\
(0.55)\end{array}$ & $\begin{array}{c}0.979 \\
(-0.64)\end{array}$ & $\begin{array}{l}1.013 \\
(0.24)\end{array}$ & $\begin{array}{c}0.994 \\
(-0.16)\end{array}$ \\
\hline $\begin{array}{l}\text { Ore and metal imports ( } \% \text { of total } \\
\text { imports) }\end{array}$ & & $\begin{array}{l}1.193^{*} \\
(1.64)\end{array}$ & $\begin{array}{l}1.212^{*} \\
(1.76)\end{array}$ & $\begin{array}{l}1.156 \\
(1.28)\end{array}$ & $\begin{array}{l}1.179 \\
(1.49)\end{array}$ & $\begin{array}{l}1.286 \\
(1.48)\end{array}$ & $\begin{array}{l}1.191^{*} \\
(1.64)\end{array}$ \\
\hline Medium income & $\begin{array}{l}3.536 \\
(1.55)\end{array}$ & $\begin{array}{l}3.140 * * \\
(2.11)\end{array}$ & $\begin{array}{l}3.434 * * \\
(2.25)\end{array}$ & $\begin{array}{l}3.822 * * \\
(2.33)\end{array}$ & $\begin{array}{l}2.920 * * \\
(2.06)\end{array}$ & $\begin{array}{l}6.719 * * \\
(2.14)\end{array}$ & $\begin{array}{l}3.230^{*} \\
(1.71)\end{array}$ \\
\hline High income non-OECD & $\begin{array}{l}6.001 \\
(1.56)\end{array}$ & $\begin{array}{l}6.048 * * * \\
(2.67)\end{array}$ & $\begin{array}{l}7.030 * * * \\
(2.95)\end{array}$ & $\begin{array}{l}8.197 * * * \\
(2.82)\end{array}$ & $\begin{array}{l}5.703 * * * \\
(2.55)\end{array}$ & $\begin{array}{l}17.409 * * * \\
\quad(2.54)\end{array}$ & $\begin{array}{l}7.392 * * * \\
(2.32)\end{array}$ \\
\hline Regional GDP growth & & & & $\begin{array}{c}1.077 * * \\
(2.43)\end{array}$ & & & \\
\hline World GDP growth & & & & $\begin{array}{c}0.874 \\
(-0.97)\end{array}$ & & & \\
\hline $\operatorname{Ln}(p)$ & $\begin{array}{l}0.019 \\
(0.18)\end{array}$ & $\begin{array}{l}0.037 \\
(0.40)\end{array}$ & $\begin{array}{l}0.050 \\
(0.49)\end{array}$ & $\begin{array}{l}0.087 \\
(0.80)\end{array}$ & $\begin{array}{l}0.075 \\
(0.83)\end{array}$ & $\begin{array}{l}0.490 \\
(4.79)\end{array}$ & - \\
\hline $\mathrm{p}$ & 1.019 & 1.037 & 1.051 & 1.091 & 1.078 & 1.277 & - \\
\hline Observations & 246 & 240 & 240 & 239 & 280 & 240 & 240 \\
\hline Countries included & 48 & 48 & 48 & 47 & 58 & 48 & 48 \\
\hline Countries using AD law & 31 & 32 & 32 & 31 & 32 & 32 & 32 \\
\hline Wald $\chi^{2}$ & $54.61 * * *$ & $53.18 * * *$ & $73.57 * * *$ & $80.53 * * *$ & $77.18 * * *$ & $61.03 * * *$ & $32.15^{* * *}$ \\
\hline
\end{tabular}

Notes: The table reports hazard ratios with robust z-statistics of the underling point estimates in brackets. A coefficient above (below) 1 implies that the variable has a positive (negative) effect on the likelihood of adoption. $p$ is the ancillary parameter of the Weibull model. * denotes significance at the $10 \%$ level, $* * 5 \%$ level, and $* * * 1 \%$ level. The frailty model in column (6) assumes an inverse Gaussian distribution for the random effects. 
Table 6: Economic significance

\begin{tabular}{|c|c|c|c|c|c|}
\hline & \multicolumn{2}{|c|}{ Decision to adopt AD law } & & \multicolumn{2}{|c|}{$\begin{array}{c}\text { Decision to start } \\
\text { using AD law }\end{array}$} \\
\hline & $\begin{array}{l}\text { \% Impact } \\
\text { on hazard }\end{array}$ & $\begin{array}{c}\text { Mean } \\
\text { (st. dev.) }\end{array}$ & & $\begin{array}{l}\text { \% Impact } \\
\text { on hazard }\end{array}$ & $\begin{array}{c}\text { Mean } \\
\text { (st. dev.) }\end{array}$ \\
\hline WTO entry in past 5 years & $\begin{array}{c}82.43 * \\
(1.88)\end{array}$ & $\begin{array}{c}0.09 \\
(0.29)\end{array}$ & $\begin{array}{l}\text { AD measures received in the } \\
\text { previous year }\end{array}$ & $\begin{array}{l}22.48^{* * *} \\
(3.86)\end{array}$ & $\begin{array}{c}0.70 \\
(1.93)\end{array}$ \\
\hline $\begin{array}{l}\text { Cumulated AD measures } \\
\text { received in the past }\end{array}$ & $\begin{array}{l}14.42 * * * \\
(3.67)\end{array}$ & $\begin{array}{c}2.19 \\
(11.80)\end{array}$ & $\begin{array}{l}\text { Number of active AD laws in } \\
\text { the same continent }\end{array}$ & $\begin{array}{l}11.24 \\
(0.50)\end{array}$ & $\begin{array}{c}4.51 \\
(3.20)\end{array}$ \\
\hline $\begin{array}{l}\text { Number of AD laws in the } \\
\text { same continent }\end{array}$ & $\begin{array}{l}73.32 * * * \\
(3.39)\end{array}$ & $\begin{array}{l}2.23 \\
(2.90)\end{array}$ & $\% \Delta$ Applied tariffs & $\begin{array}{l}-34.83 * \\
(-1.78)\end{array}$ & $\begin{array}{c}-6.73 \\
(36.40)\end{array}$ \\
\hline$\% \Delta$ Openness index & $\begin{array}{l}49.60 * * \\
(2.45)\end{array}$ & $\begin{array}{c}2.78 \\
(8.26)\end{array}$ & $\begin{array}{l}\text { Food imports }(\% \text { of total } \\
\text { imports })\end{array}$ & $\begin{array}{l}3.35 \\
(0.17)\end{array}$ & $\begin{array}{l}11.47 \\
(5.65)\end{array}$ \\
\hline Industry VA (\% GDP) & $\begin{array}{l}53.89 * * \\
(1.96)\end{array}$ & $\begin{array}{l}28.83 \\
(12.11)\end{array}$ & $\begin{array}{l}\text { Ore and metal imports ( } \% \text { of } \\
\text { total imports) }\end{array}$ & $\begin{array}{l}30.94 \\
(1.42)\end{array}$ & $\begin{array}{c}2.54 \\
(1.53)\end{array}$ \\
\hline Services VA ( $\%$ GDP) & $\begin{array}{l}39.76 \\
(1.39)\end{array}$ & $\begin{array}{c}48.30 \\
(11.65)\end{array}$ & Medium income & $\begin{array}{c}214.02 * * \\
(2.11)\end{array}$ & $\begin{array}{c}0.65 \\
(0.48)\end{array}$ \\
\hline Medium income & $\begin{array}{l}80.65 \\
(1.12)\end{array}$ & $\begin{array}{c}0.50 \\
(0.50)\end{array}$ & High income non-OECD & $\begin{array}{c}504.84 * * * \\
(2.67)\end{array}$ & $\begin{array}{c}0.06 \\
(0.24)\end{array}$ \\
\hline High income non-OECD & $\begin{array}{c}79.11 \\
(-0.22)\end{array}$ & $\begin{array}{c}0.08 \\
(0.27)\end{array}$ & & & \\
\hline High income $O E C D$ & $\begin{array}{c}78.82 \\
(-0.17)\end{array}$ & $\begin{array}{c}0.02 \\
(0.15)\end{array}$ & & & \\
\hline
\end{tabular}

Notes: The table reports the percentage impact of a one-standard deviation change in each regressor on the hazard rate, except for dummy variables (in italics in the table) where the effect of the dummy switching from 0 to 1 is reported. The other column reports the mean and standard deviation of each regressor. Robust z-statistics in brackets * denotes significance at the $10 \%$ level, ** $5 \%$ level, and *** $1 \%$ level. 


\section{REFERENCES}

Anderson, K. (1993), "Antidumping Laws in the US; Use and Welfare Consequences", Journal of World Trade 27: 99-117.

Blanchflower, D.G. (2006), “A Cross-Country Study of Union Membership”, IZA Discussion Paper No. 2016.

Blonigen, B. and Bown, C. (2003), “Antidumping and Retaliation Threats”, Journal of International Economics 60: 249-273.

Blonigen, B. and Prusa, T.J. (2003), “Antidumping”, in: Choi, E.K. and Harrigan, J. (eds.), Handbook of International Trade, Oxford, U.K. and Cambridge, MA: Blackwell Publishers.

Bown, C. (2004), “ How different are Safeguards from Antidumping? Evidence from the US Trade Policies toward steel”, working paper, Brandeis University.

Bown, C. (2006), “The WTO and Antidumping in Developing Countries”, working paper, Brandeis University.

Cleves, M.A., Gould, W.W. and Gutierrez, R.G. (2004), An Introduction to Survival Analysis Using Stata (Revised Edition), College Station TX: Stata Press.

DeVault, J. (1996), “The Welfare Effects of US Antidumping Duties”, Open Economies Review 7: 1933.

Feinberg, R. and Reynolds, K. (2006), "The Spread of antidumping Regimes and the role of Retaliation in Filings", Southern Economic Journal 72: 877-890.

Finger, J.M., Ng, F., and Wangchuk S. (2002), “Antidumping as a Safeguard Policy”, in Stern, R. (ed.), Issues and Options for US-Japan Trade Policies, Ann Arbor: University of Michigan Press.

Gallaway, M.C., Blonigen, B.A., and Flynn, J.E. (1999), "Welfare Costs of the US Antidumping and Countervailing Duty Laws", Journal of International Economics 49: 211-244.

GATT, 1958. Anti-dumping and Countervailing Duties. Geneva, GATT/1958-2.

Gawande, K. and Krishna, P. (2003), "The Political Economy of Trade Policy: Empirical Approaches", in Choi, K.C. and Harrigan, J. (eds.), Handbook of International Trade, Oxford: Blackwell.

Grossman, G. and Helpman, E. (1994), "Protection for sale", American Economic Review 84: 833850.

Grossman, G. and Wauters, J. (2007), "United States Sunset Reviews of Anti-dumping Measures on Oil country Tubular goods from Argentina", paper presented at a conference organized by the American Law Institute at the WTO in Geneva.

Hillman, A. (1982), "Declining Industries and Political support Protectionist Motives", American Economic Review 72: 1180-1187.

Hoekman, B. and Mavroidis, P.C. (1996), "Dumping, Antidumping and Antitrust", Journal of World Trade 30: 27-52.

Ikenson, D.J. (2002), “Dump Antidumping Regs”, National Review Online. 
ILO (1998), World Labour Report: Industrial Relations, Democracy, and Social Stability 1997-98, Geneva: ILO.

Irwin, D.A. (1998), "Did late nineteenth Century tariffs Promote Infant Industries? Evidence from the Tinplate Industry", NBER working paper 6835.

Ishikawa, J. and Lawrence, S. (2005), “Trade Union Membership and Collective Bargaining Coverage: Statistical Concepts, Methods and Findings”, DIALOGUE Paper No. 10, Geneva: ILO.

Knetter M. and Prusa, T.J. (2003), "Macroeconomic Factors and Antidumping Filings: Evidence from Four Countries", Journal of International Economics 61: 1-17.

Konings, J., Vandenbussche, H., and Springael, L. (2001), "Import Diversion under European Antidumping Policy", Journal of Industry, Competition and Trade 1: 283-299.

Kuruvilla, S, Das, S., Kwon, H. and Kwon, S. (2002), "Trade Union Growth and Decline in Asia”, British Journal of Industrial Relations 40: 431-461.

Lindsey, B. and Ikenson, D.J. (2001), "Coming Home to Roost: Proliferating Antidumping Laws and the Growing Threat to U.S. Exports", Cato Institute Trade Policy Analysis 14.

Mastel, G. (1999), “The U.S. Steel Industry and Antidumping Law”, Challenge.

Messerlin, P. (1990), “Anti-Dumping Regulations or Pro-Cartel Law? The EC Chemical Cases", The World Economy 13: 465-492.

Messerlin, P. (1994), "Should Antidumping Rules be Replaced by National or International Competition Rules?", Aussenwirtschaft 49: 351-374.

Moore, M. (2005), “Antidumping Reform in the Doha Round: a Pessimistic Appraisal”, mimeo.

Moore, M. and Zanardi, M. (2006), "Does Antidumping Use Contribute to Trade Liberalization? An Empirical Analysis", CentER working paper 61.

Nelson, D. (2006), "The Political Economy of Antidumping: a Survey”, European Journal of Political Economy 22: 554-590.

Niels, G. (2003), “Trade Diversion and Trade Destruction Effects of Antidumping Policy: Empirical Evidence from Mexico", mimeo.

Niels, G. and ten Kate, A. (2006), "Antidumping Policy in Developing Countries: Safety Valve or Obstacle to Free Trade?", European Journal of Political Economy 22: 618-638.

Prusa, T.J. (1992), “Why are so Many Antidumping Petitions Withdrawn?", Journal of International Integration 33: 1-20.

Prusa, T.J. (1994), "Pricing Behavior in the Presence of Antidumping Law", Journal of Economic Integration 9: 260-289.

Prusa, T.J. (1997), "The Trade Effects of U.S. Antidumping Actions", in Feenstra, R. (ed.), The Effects of US Trade Protection and Promotion Policies, Chicago: University of Chicago Press.

Prusa, T.J. (2001), "On the Spread and Impact of Antidumping", Canadian Journal of Economics 34: 591-611. 
Prusa, T.J. and Skeath, S. (2002), "The Economic and Strategic Motives for Antidumping Filings", Weltwirtschaftliches Archiv 138: 389-413.

Prusa, T.J. and Skeath, S. (2005), “Modern Commercial Policy: Managed Trade or Retaliation?”, in Choi, E.K. and Hartigan, J. (eds.), Handbook of International Trade, vol. 2, Oxford, U.K. and Cambridge, MA: Blackwell Publishers.

Rauch, J. (1999), "Networks versus Markets in International Trade", Journal of International Economics 48: 7-35.

Roberts, K.M. and Wibbels, E. (1999), "Party Systems and Electoral Volatility in Latin America: A Test of Economic, Institutional, and Structural Explanations", American Political Science Review 93: 575-590.

Sapir, A. (2006), "Some Ideas for Reforming the Community Anti-Dumping Instrument", paper prepared for EU Trade Commissioner Mr Mandelson for seminar on Trade Defense Instruments 11 July 2006 (http://www.bruegel.org).

Sapir, A. and Trachtman, J.P. (2007), "Subsidization, Price depression and Expertise: Causation and Precision in Upland Cotton", paper presented at a conference organized by the American Law Institute at the WTO in Geneva.

Shin, H.J. (1998), "Possible Instances of Predatory Pricing in Recent U.S. Antidumping Cases", in Lawrence, R. (ed.), Brookings Trade Forum 1998, Washington DC: Brookings Institute Press.

Staiger, W.R. and Wolak, F.A. (1994), "Measuring industry-specific protection:antidumping in the United States", Brookings Papers on Economic Activity, Microeconomics, 51-118.

US Department of Labor, Foreign Labor Trends (various issues).

US International Trade Commission, (1995), The Economic Effects of Antidumping and Countervailing Duty Orders and Suspension Agreements. Investigation No. 332-344. Publication 2900. Washington DC.

Vandenbussche, H., Veugelers, R. and Konings, J. (2001), "Union wage bargaining and European Antidumping Policy", Oxford Economic Papers 53: 297-317.

Vandenbussche, H. and Zanardi, M. (2007), "The Global Chilling Effects of Antidumping Proliferation", revised version of CEPR discussion paper 5597 (2006).

Veugelers, R., Vandenbussche, H., (1999), "European Anti-Dumping Policy and the Profitability of National and International Collusion”, European Economic Review 43: 1-28.

Visser, J. (2003), "Unions and Unionism Around the World", in Addison, J.T. and Schnabel, C. (eds.), International Handbook of Trade Unions, Cheltenham, UK: Edward Elgar Publishing Ltd.

World Trade Organization (1999), Communication from India, document WT/GC/W/200.

Zanardi, M. (2004a), “Antidumping: What are the Numbers to Discuss at Doha?", The World Economy 27: 403-433.

Zanardi, M., (2004b), “Antidumping Law as a Collusive Device”, Canadian Journal of Economics 37: 95-122. 


\section{DATA APPENDIX}

\section{Table A.1. Description and sources of variables}

\begin{tabular}{|c|c|c|}
\hline Variables & Description & Sources \\
\hline Adoption AD law & $\begin{array}{l}\text { Year of adoption of AD law. Number of countries } \\
\text { with AD laws. }\end{array}$ & Zanardi (2004a) and authors' updates. \\
\hline $\mathrm{AD}$ variables & $\begin{array}{l}\text { Variables related to the number of initiations and } \\
\text { measures targeted to each country (in a given year } \\
\text { or cumulated) at a sectoral level. }\end{array}$ & Zanardi (2004a) and Moore and Zanardi (2006). \\
\hline Openness index & Index of "Freedom to trade internationally". & $\begin{array}{l}\text { Economic Freedom Index published by the Fraser } \\
\text { Institute. }\end{array}$ \\
\hline Applied tariffs & Average (unweighted) applied tariff rates. & $\begin{array}{l}\text { World Bank: } \\
\text { http://siteresources.worldbank.org/INTRES/Resourc } \\
\text { es/tar2005.xls }\end{array}$ \\
\hline Union density & Dummy variables based on trade union density. & $\begin{array}{l}\text { AIAS, Blanchflower (2006), ILO (1998), Ishikawa } \\
\text { and Lawrence (2005), Kuruvilla et al. (2002), OECD } \\
\text { - Labour Market Statistics, Roberts and Wibbels } \\
\text { (1999), US Department of Labor, Visser (2003). }\end{array}$ \\
\hline $\begin{array}{l}\text { Skilled/unskilled } \\
\text { population }\end{array}$ & $\begin{array}{l}\text { Ratio of skilled to unskilled people aged } 15 \text { or } \\
\text { older (interpolated). }\end{array}$ & Barro-Lee dataset \\
\hline Beliefs & $\begin{array}{l}\text { Number of Ph.D. students studying in the US } \\
\text { divided by population aged } 15 \text { or older } \\
\text { (interpolated). }\end{array}$ & $\begin{array}{l}\text { National Science Foundation for students and United } \\
\text { Nations for populations. }\end{array}$ \\
\hline $\begin{array}{l}\text { Macro-economic } \\
\text { variables }\end{array}$ & $\begin{array}{l}\text { Variables related to a country economic structure } \\
\text { and performance (e.g., GDP, exchange rate, FDI). }\end{array}$ & $\begin{array}{l}\text { World Development Indicators. CHELEM for } \\
\text { Taiwan. }\end{array}$ \\
\hline WTO membership & $\begin{array}{l}\text { Membership of the GATT/WTO and year of } \\
\text { accession. }\end{array}$ & WTO website. \\
\hline
\end{tabular}


Table A.2: Robustness checks: one channel at the time

\begin{tabular}{|c|c|c|c|c|c|c|c|c|c|c|}
\hline & \multirow{2}{*}{$\begin{array}{c}\text { Retaliation } \\
(1)\end{array}$} & \multirow{2}{*}{$\begin{array}{c}\text { Contagion } \\
(2)\end{array}$} & \multicolumn{2}{|c|}{ Safety valve } & \multicolumn{4}{|c|}{ Political economy } & \multicolumn{2}{|c|}{ Macro effects } \\
\hline & & & (3) & (4) & (5) & $(6)$ & (7) & (8) & (9) & (10) \\
\hline $\begin{array}{l}\text { Cumulated AD measures } \\
\text { in steel in the past }\end{array}$ & $\begin{array}{c}1.014 * * * \\
(4.46)\end{array}$ & & & & & & & & & \\
\hline $\begin{array}{l}\text { Number of AD laws in the } \\
\text { same continent }\end{array}$ & & $\begin{array}{l}1.203 * * * \\
(5.63)\end{array}$ & & & & & & & & \\
\hline$\% \Delta$ Openness Index & & & $\begin{array}{l}1.020 \\
(1.52)\end{array}$ & & & & & & & \\
\hline$\% \Delta$ Applied Tariffs & & & & $\begin{array}{l}0.985 * * * \\
(-3.00)\end{array}$ & & & & & & \\
\hline Industry VA (\% GDP) & & & & & $\begin{array}{l}1.042 * * * \\
(3.47)\end{array}$ & & & & & \\
\hline Services VA (\% GDP) & & & & & $\begin{array}{l}1.043 * * * \\
(3.62)\end{array}$ & & & & & \\
\hline $\begin{array}{l}\text { Food imports ( } \% \text { of total } \\
\text { imports) }\end{array}$ & & & & & & $\begin{array}{l}0.936 * * * \\
(-2.68)\end{array}$ & & & & \\
\hline $\begin{array}{l}\text { Ore and metal imports (\% } \\
\text { of total imports) }\end{array}$ & & & & & & $\begin{array}{l}1.294 * * * \\
(3.38)\end{array}$ & & & & \\
\hline Union density btw $21-40 \%$ & & & & & & & $\begin{array}{l}1.241 \\
(0.64)\end{array}$ & & & \\
\hline Union density above $40 \%$ & & & & & & & $\begin{array}{l}1.652 \\
(1.53)\end{array}$ & & & \\
\hline Skill/unskilled population & & & & & & & & $\begin{array}{l}1.494 \\
(1.28)\end{array}$ & & \\
\hline Medium income & & & & & & & & & $\begin{array}{l}4.042 * * * \\
(3.91)\end{array}$ & \\
\hline High income non-OECD & & & & & & & & & $\begin{array}{l}1.554 \\
(0.65)\end{array}$ & \\
\hline High income OECD & & & & & & & & & $\begin{array}{l}5.208 \\
(1.43)\end{array}$ & \\
\hline Beliefs & & & & & & & & & & $\begin{array}{c}170.848 \\
(1.20)\end{array}$ \\
\hline $\operatorname{Ln}(p)$ & $\begin{array}{l}0.739 * * * \\
(4.46)\end{array}$ & $\begin{array}{l}0.242 \\
(1.50)\end{array}$ & $\begin{array}{l}0.642 * \\
* * \\
*\end{array}$ & $\begin{array}{l}0.533 * * * \\
(2.97)\end{array}$ & $\begin{array}{l}0.710 * * * \\
(4.81)\end{array}$ & $\begin{array}{l}0.793 * * * \\
(5.23)\end{array}$ & $\begin{array}{l}0.747 * * * \\
\quad(5.21)\end{array}$ & $\begin{array}{l}0.641 * * * \\
(3.74)\end{array}$ & $\begin{array}{l}0.760 * * * \\
(5.40)\end{array}$ & $\begin{array}{l}0.716 * * * \\
\quad(5.41)\end{array}$ \\
\hline $\mathrm{p}$ & 2.094 & 1.274 & 1.901 & 1.703 & 2.033 & 2.210 & 2.111 & 1.899 & 2.139 & 2.046 \\
\hline Observations & 1,795 & 1,843 & 1,232 & 929 & 1,572 & 1,123 & 1,011 & 1,009 & 1,843 & 1,819 \\
\hline Countries included & 108 & 108 & 81 & 95 & 102 & 106 & 68 & 64 & 108 & 111 \\
\hline Countries adopting AD law & 60 & 61 & 51 & 50 & 59 & 56 & 52 & 37 & 61 & 61 \\
\hline Wald $\chi^{2}$ & $19.90 * * *$ & $31.72 * * *$ & 2.30 & $8.99 * * *$ & $17.18 * * *$ & $17.18 * * *$ & 2.34 & 1.65 & $16.81 * * *$ & 1.45 \\
\hline
\end{tabular}

Notes: The table reports hazard ratios with robust z-statistics of the underling point estimates in brackets. A coefficient above (below) 1 implies that the variable has a positive (negative) effect on the likelihood of adoption. $p$ is the ancillary parameter of the Weibull model.* denotes significance at the $10 \%$ level, ** $5 \%$ level, and *** $1 \%$ level. 


\section{BOX 1: ANTIDUMPING: HOW IT WORKS AND IS TREATED BY THE WTO}

Antidumping is by now a standard protectionist tool used by many countries. As such, it was allowed by the GATT and now by the WTO as a form of contingent protection that can be invoked when certain conditions are satisfied. In essence, AD duties can be imposed to eliminate the effects of dumping on domestic producers. Dumping is generally defined as exporting below "normal value", which can be interpreted as an export price lower than the price charged by the exporter in its own home market or pricing below production cost "plus a reasonable amount for administrative, selling and general costs and for profits."

The use of $\mathrm{AD}$ is based on the notion that dumping is an unfair business strategy and therefore the level playing field must be re-established through government intervention. Competition laws may seem more appropriate to deal with this type of issues (i.e., price discrimination and market segmentation) but the international dimension of the problem would call for a supranational authority while the administration of a trade instrument rests only within the jurisdiction of the importing country.

In practical terms, $\mathrm{AD}$ procedures begin when a domestic industry files an $\mathrm{AD}$ petition with the relevant authority. ${ }^{31}$ If all the necessary legal requirements are fulfilled, an official investigation is initiated whose main objectives are to ascertain the existence of dumping and that this is causing material injury to the domestic industry. If these two conditions are verified, trade protection can be granted. Protection can take different forms. The simplest one is the imposition of AD duties. Alternatively, foreign firms can voluntary decide to increase their prices by agreeing on a price undertaking that eliminates injury to the domestic firms. Importantly, the duties or the agreed prices are firm-specific and are calculated for each dumping exporter.

Even before reaching the final decision, provisional $\mathrm{AD}$ duties can be imposed if preliminary determinations by the importing country have established the existence of dumping and injury and there are reasons to believe that without such measures injury would continue during the investigation period. Overall, the investigation should not take more than a year to reach completion (except in special circumstances). Following the implementation of the Uruguay AD Code, AD duties and price undertakings should be terminated at most five years from their introduction, except if a review determines that dumping and injury would continue otherwise.

As illustrated above, AD is an exception to the GATT/WTO principle of non-discrimination. Not only different countries receive different treatment but also different firms within each country are treated differently when exporting the same product. As a matter of fact, although the first AD law predates the GATT by more than forty years, AD procedures soon became a standard tool of the

\footnotetext{
${ }^{31}$ A petition is valid if it is supported by a majority of the industry (measured in terms of production).
} 
GATT $^{32}$ In fact, already in 1956 the contracting parties to the GATT decided to have a systematic study of the AD legislation and of the extent of its use across members (GATT, 1958).

During the Kennedy Round of the GATT, the first AD Code was negotiated and it entered into force in 1967. A similar situation occurred during the Tokyo Round with a new AD Code adopted in 1980. The Kennedy and Tokyo AD Code were not part of the GATT Agreements and as such they required specific approval by each country in order to be valid. ${ }^{33}$ Instead, the Uruguay Round AD Code that entered into force on January 1st 1995 departs from this rule since it is an integral part of the WTO Agreement. This implies that each member country is automatically bound but its provisions, should a member country decide to have an AD law. As such, the WTO AD Agreement represents the yardstick against which national $\mathrm{AD}$ laws are judged and, at the same time, it provides a model for countries that decide to introduce AD procedures. However, it important to emphasize that there is no formal requirement for a country that is a member or that is becoming a member of the WTO to have an AD law.

The WTO AD Agreement only provides the general framework that regulates the use of AD but it leaves flexibility to each country in the way it decides to implement it. This leads to a variety of practices. For example, in some countries (e.g., Canada, China, USA) two different authorities investigate the existence of dumping and of material injury while in other cases just one agency is in charge of both tests (e.g., EU, India, Mexico). Some countries also seem to prefer negotiated agreements to the formal imposition of AD duties much more than others (e.g., EU and South Korea versus Brazil and USA). An important aspect is that some AD laws may include a public interest test to judge the merit of AD protection vis-a-vis the welfare of the country as a whole. Noticeably, the EU has such a provision (the so-called "Community Interest test") although it seems that it is rarely invoked to dismiss an $\mathrm{AD}$ case.

\section{BOX 2: SHORT LITERATURE REVIEW OF THE EFFECTS OF ANTIDUMPING}

The economic literature on $\mathrm{AD}$ is very long both in its theoretical and empirical dimensions. Here, we will highlight only some of the results that are relevant for the current study and that are not already discussed in the main text of the paper. ${ }^{34}$

At first, a clarification is necessary. Although $\mathrm{AD}$ is a response to dumping, the discussion on $\mathrm{AD}$ is now independent from the one about dumping, as a the result of an increasingly long literature that points out that the occurrence of dumping is not anymore the defining aspect in the application of $\mathrm{AD}$ duties and in the industries' motivations in filing such petitions. ${ }^{35}$ Indeed, when investigating the

\footnotetext{
${ }^{32}$ Canada was the first country to adopt an AD law in 1904 while the GATT was established in 1947.

${ }^{33}$ For example, the United States never signed the Kennedy AD code.

${ }^{34}$ See Blonigen and Prusa (2003) and Nelson (2006) for longer surveys of AD.

${ }^{35}$ The legal definition of dumping provided by the WTO AD Agreement is also far from the economic definition.
} 
determinants of worldwide AD filings, Prusa and Skeath (2005) "reject the notion that the rise in AD activity is solely explained by an increase in unfair trading" since they find clear evidence that AD actions are motivated by strategic reasons. And in a recent survey on AD, Blonigen and Prusa (2003) emphasize how AD is simply a modern form of protection since "all but AD's staunchest supporters agree that $\mathrm{AD}$ has nothing to do with keeping trade "fair"."

On top of this disassociation between the occurrence of dumping and the use of $\mathrm{AD}$, the general negative attitude of economists with respect to $\mathrm{AD}$ is that it lacks economic justification except in special cases. In fact, the only rationale to use $\mathrm{AD}$ is if the dumping exporters are trying to eliminate the domestic industry in order to become monopolists (i.e., predatory dumping). However, such cases seem to be very rare (e.g., Shin, 1998). Then, it is no surprise that various studies conclude that the use of AD results in net welfare losses for a country. Gallaway et al. (1999) use a computable general equilibrium model to estimate that the annual welfare loss of affirmative $\mathrm{AD}$ and countervailing actions for the US are in the range of 4 billion US\$ a year, second only to the costs resulting from the Multifibre Agreement. ${ }^{36}$ The US International Trade Commission (1995), DeVault (1996) and Anderson (1993) reach the same qualitative conclusions when analyzing specific US AD cases. Although the existing literature focuses on the US, similar qualitative conclusions should hold for other AD users. These estimates, however, consider only the distortions due to the trade flows directly subject to AD measures. Therefore, they should be taken as lower bounds of the actual effects since many strategic effects are at play when firms internalize the existence of AD laws.

Among the strategic effects, it is known that $A D$ procedures can help domestic and international collusion. Theoretically, AD laws can act as price floors (Prusa, 1994), which facilitate collusive outcomes. Moreover, faced with the prospect of AD duties, domestic and foreign firms have an incentive to strike a deal and share the rents that would otherwise be collected by the importing country as tariff revenue (Prusa, 1992; Veugelers and Vandenbussche, 1999; Zanardi, 2004b). Even more alarming, the need for domestic firms to cooperate during the various phases of the investigation can lead to the creation of sustainable cartels (Messerlin, 1990). In the US, this possibility is reinforced by the Noerr-Pennington legal doctrine which provides some antitrust exemption for US firms that cooperate during $\mathrm{AD}$ proceedings.

When collusion is achieved or trade protection (e.g., AD duties or price undertakings) is granted, the trade flows of goods under scrutiny obviously decrease. However, Staiger and Wolak (1994) provide econometric evidence that imports are also (negatively) affected by preliminary affirmative decisions. Therefore, firms may actually file AD petitions because of these investigation effects (i.e., harassment) although they do not expect final duties to be imposed.

As for the trade effects resulting from $\mathrm{AD}$ duties, it is important to remember that such duties are applied discriminatory to some (exporters within) countries, giving rise to the possibility of trade

\footnotetext{
${ }^{36}$ Countervailing duties are imposed on imports that receive illegal subsidies in their home country.
} 
diversion. This implies that $\mathrm{AD}$ protection leads to a shift in the origin of imports, with an increase of imports from countries not named in the AD investigation. Although trade diversion can offset the reduction of trade from named countries (thus reducing the benefit for domestic producers), it involves sourcing from inefficient exporters. Prusa (1997) finds clear evidence of (less than fully offsetting) trade diversion for a sample of US cases. Instead, Konings et al. (2001) and Niels (2003) conclude that for European and Mexican $\mathrm{AD}$ duties trade diversion is much lower, suggesting that $\mathrm{AD}$ is more effective in keeping imports out.

Because of the various effects that the existence and use of $\mathrm{AD}$ laws can generate, it is inherently difficult to quantity the total effects stemming from the overall AD system. Still, Vandenbussche and Zanardi (2007) try to overcome some of the limitations of the literature by using a gravity equation approach and applying it to the bilateral imports of a large sample of importing countries and new users of $\mathrm{AD}$. Their conclusion is that $\mathrm{AD}$ can have serious trade depressing effects on imports. In particular, those countries that recently adopted AD laws and intensively use them experience annual trade losses of about $8.9 \%$. In order to provide some perspective, these effects are related to the growth of imports due to the trade liberalization that some of these countries undertook in recent years. The comparison illustrates the chilling effects that $\mathrm{AD}$ policy can have since for countries like India and Taiwan the dampening effects of AD laws on trade flows are found to largely offset the gains from trade liberalization. 
Département des Sciences Économiques de l'Université catholique de Louvain

Institut de Recherches Économiques et Sociales

Place Montesquieu, 3

1348 Louvain-la-Neuve, Belgique 